\title{
Dendritic Cells for Active Anti-Cancer Immunotherapy: Targeting Activation Pathways Through Genetic Modification
}

\author{
Karine Breckpot ${ }^{1,2, *}$ and David Escors ${ }^{2}$ \\ ${ }^{1}$ Laboratory of Molecular and Cellular Therapy, Department of Physiology-Immunology, Medical \\ School of the 'Vrije Universiteit Brussel', Laarbeeklaan 103 building E, 1090 Jette, Belgium \\ ${ }^{2}$ Division of Infection and Immunity, Medical School of the Royal Free and University College \\ London, 46 Cleveland Street, London W1T 4JF, United Kingdom
}

\begin{abstract}
Tumour immunotherapy has become a treatment modality for cancer, harnessing the immune system to recognize and eradicate tumour cells specifically. It is based on the expression of tumour associated antigens (TAA) by the tumour cells and aims at the induction of TAA-specific effector $\mathrm{T}$ cell responses, whilst overruling various mechanisms that can hamper the anti-tumour immune response, e.g. regulatory $\mathrm{T}$ cells (Treg). (Re-) activation of effector $\mathrm{T}$ cells requires the completion of a carefully orchestrated series of specific steps. Particularly important is the provision of TAA presentation and strong stimulatory signals, delivered by co-stimulatory surface molecules and cytokines. These can only be delivered by professional antigen-presenting cells, in particular dendritic cells (DC). Therefore, DC need to be loaded with TAA and appropriately activated. It is not surprising that an extensive part of DC research has focused on the delivery of both TAA and activation signals to DC, developing a one step approach to obtain potent stimulatory DC. The simultaneous delivery of TAA and activation signals is therefore the topic of this review, emphasizing the role of DC in mediating $\mathrm{T}$ cell activation and how we can manipulate DC for the pill-pose of enhancing tumour immunotherapy. As we gain a better understanding of the molecular and cellular mechanisms that mediate induction of TAA-specific T cells, rational approaches for the activation of $\mathrm{T}$ cell responses can be developed for the treatment of cancer.
\end{abstract}

\section{Keywords}

Dendritic cell; toll like receptor; transcription factor; cytotoxic T lymphocytes; gene therapy; cancer

\section{GENERAL INTRODUCTION}

The concept of a central role for the immune system in the treatment of diseases is longstanding. Already a century ago George Bernard Shaw postulated that the stimulation of phagocytes is at bottom the only genuinely scientific treatment for all diseases [1]. At the same time, Paul Ehrlich formulated his immune surveillance hypothesis, stating that the immune system can distinguish self from non-self and that the latter can be eliminated without damaging the former [2]. He put forward the fundamental immunological idea of unique receptors on immune cells. It took another 70 years to identify - what we now know

(C) 2009 Bentham Science Publishers Ltd.

*Address correspondence to this author at the Laboratory of Molecular and Cellular Therapy, Department of Physiology-Immunology, Medical School of the 'Vrije Universiteit Brussel', Laarbeeklaan 103 building E, 1090 Jette, Belgium; kbreckpo@ vub.ac.be. 
as - the T cell receptor (TCR) (reviewed by [3]). Originally these concepts were devised for explaining immune responses against foreign invaders. However, Burnet and Thomas, translated these in view of anti-tumour immune responses in their so-called tumour surveillance hypothesis, proposing a model in which tumour cells are recognized as foreign by the immune system and subsequently specifically eliminated without damaging their healthy counterparts, much in the same way as for virus infected cells, thus avoiding autoimmunity [4].

The identification of antigens that are specifically expressed by the tumour, but not by normal tissues offered a rationale for this hypothesis. These tumour-associated antigens (TAA) can be divided in several groups according to their expression pattern [5]. As melanoma constitutes the most immunogenic cancer, most of the TAA known to date were identified from melanoma tumours. It has been demonstrated that each of these antigens can give rise to a number of epitopes that will be presented in major histocompatibility (MHC) class I or class II molecules and that these MHC/peptide complexes can be recognized by the TCR of $\mathrm{CD}^{+}$cytotoxic $\mathrm{T}$ lymphocytes (CTL) and CD4 ${ }^{+} \mathrm{T}$ cells, respectively [6]. The former are able to kill tumour cells by secreting cytolytic granules or activating death receptor-associated apoptosis pathways, while $\mathrm{CD} 4^{+}$Th 1 cells secrete cytokines that assist in the activation and maintenance of CTL, as well as in inhibition of tumour cell proliferation [7]. Extensive research into these TAA and immune responses directed against them has instigated attempts for the manipulation of the anti-tumour immune response by actively trying to stimulate immunity - CTL and Th 1 cells - against these TAA and consequently against the tumour itself. These therapeutic vaccination approaches have been developed as an alternative or additional treatment regimen to classic therapies, such as radiotherapy, chemotherapy and surgical removal of tumours.

It has to be mentioned that although cancer cells can potentially be distinguished from normal cells through this arsenal of TAA, most of these TAA are still considered as autoantigens by the immune system. As a consequence, several tolerogenic mechanisms as well as different modes of active inhibition will impede the induction of a productive anti-tumour immune response. A manifestation of this phenomenon is the presence of high numbers of CTL in the tumour and the periphery without measurable tumour regression [8]. Taken together, for any therapeutic vaccination strategy to be successful, it is crucial not only to induce a specific immune response against the tumour, but also to overcome intrinsic tolerogenic and suppressive mechanisms.

\section{DC-BASED THERAPY OF CANCER}

Immunotherapy seeks to mobilize a patient's immune system for therapeutic benefit. It can be passive, i.e. transfer of immune effector cells (T cells) or proteins (antibodies), or active through vaccination. In cancer, passive immunotherapy can lead to some objective clinical responses, thus demonstrating that the immune system can reject tumours [9]. However, passive immunotherapy is not expected to yield long-lived memory $\mathrm{T}$ cells that might control tumour outgrowth.

Active immunotherapy using TAA and adjuvant has the potential to induce both tumourspecific effector and memory T cells. In this regard DC, known as the professional antigenpresenting cells of our immune system, are considered as nature's adjuvant and are therefore well studied as a cellular anti-cancer vaccine [10].

\section{Subsets}

DC were first visualized as Langerhans cells in the skin in 1868 by Paul Langerhans, then Ralph Steinman and Cohn identified DC from mouse spleen in 1973 [11]. They constitute a 
distinct lineage of white blood cell development, which was originally thought to share a progenitor with other phagocytes, such as macrophages and granulocytes. Although granulocyte-macrophage colony stimulating factor (GM-CSF) was recognized as a key stimulating cytokine for these populations, DC were regarded as a separate cell lineage, because of their unique properties [12]. The intricate development and life cycle of DC is reviewed in detail in numerous reviews [13-15]. In summary, DC can originate from both lymphoid and myeloid progenitors, giving rise to several distinct subsets, which are defined by the expression of surface markers and by their function [16]. Although the definition of DC subsets in mouse is much more complicated than in human, they can be broadly divided into myeloid DC and plasmacytoid DC. These DC subsets differ in their life span, cytokine production, receptors for antigen uptake, receptors for microbial ligands, which are essentially pathogen recognition receptors, such as toll like receptors (TLR), as well as receptors for cytokines and chemokines and linked herewith their function. Plasmacytoid DC, characterized by the expression of BDCA-2 and a relative long life span are able to make high amounts of interferon- $a$ (IFN- $a$ ) in response to viral infection $[17,18]$. These DC can - although very weakly - capture soluble and particulate antigens [19], respond to IL-3 [20] and express TLR9, which engages bacterial DNA and demethylated CpG DNA [21]. In contrast to plasmacytoid DC, myeloid DC respond to GM-CSF rather than IL-3 [22] and are characterized by the high expression of CD11c and low expression of CD123 [23]. They express a number of endocytic receptors that are not found on plasmacytoid DC and that enable them to efficiently sample the environment [15]. They are further characterized by their ability to make IL-12 in response to several stimuli, amongst which ligands of TLR2 (lipopeptides), TLR3 (dsRNA) and TLR4 (bacterial cell wall components) [24].

It has to be mentioned that although production of IFN-a is the major function of plasmacytoid DC and production of IL-12 is the major function of myeloid DC, both can be stimulated to produce IL-12 or IFN-a, respectively [25-27]. This cytokine pattern induced upon interaction of pathogen associated patterns with pathogen recognition receptors is part of an important final stage of DC differentiation, i.e. maturation, which comprises more than up-regulation of cytokines and which is pivotal for determining the subsequent immune response. The maturation of DC and the induction of immunity versus tolerance are discussed in more detail in the following section.

\section{Regulation of T Cell Immunity by DC}

DC have a remarkable functional plasticity, inducing either tolerance or immunity. The hypothesis is that distinct DC developmental and activation stages play a role in the induction of tolerance versus immunity. This is correlated with the two-signal model of $\mathrm{T}$ cell stimulation, in which it is proposed that a productive $\mathrm{T}$ cell immune response requires specific recognition of MHC/peptide complexes by the TCR (signal 1) along with signalling through co-stimulatory molecules (signal 2). Indeed both immature myeloid and plasmacytoid DC, have been described to induce T cell tolerance [28-30], whereas both mature DC types have shown to induce immunity [31-33].

Immature DC are specialized in capturing antigens. They efficiently take up pathogens, apoptotic cells and antigens from the environment by phagocytosis, macropinocytosis, or endocytosis, process these, but are considered to be unable to present these antigens efficiently to T cells [34]. Therefore, immature DC are believed to induce T cell anergy and/ or Treg [35, 36]. Indeed, in steady-state conditions, DC remain immature and tissueresident, expressing small amounts of MHC molecules as well as co-stimulatory molecules, hence inducing $\mathrm{T}$ cell anergy instead of T cell activation upon DC-T cell interaction [37]. Furthermore, injection of immature DC in humans can be tolerogenic [28, 38, 39]. On the other hand, mature DC are considered to be immunogenic. Maturation of DC can be induced by a variety of signals, such as microorganisms [40, 41], cytokines [42], interaction with 
$\mathrm{CD}^{+}$Th cells [43-45] and chemicals like haptens [46-48]. DC maturation is associated with several coordinated events, including: (a) loss of endocytic and/or phagocytic receptors; (b) changes in morphology; (c) up-regulation of MHC molecules, co-stimulatory molecules such as CD40, CD80, CD83 and CD86, adhesion molecules and chemokine receptors, such as CCR7 [10]. The latter is one of the first changes and enables the DC to migrate from the peripheral tissue to the $\mathrm{T}$ cell areas of the draining lymphoid organs [49], where DC present peptides, derived from antigens acquired in the periphery, in the context of MHC to passing $\mathrm{T}$ cells. The phenotypic changes - high expression of antigen presenting, co-stimulatory and adhesion molecules - make mature DC potent inducers of T cell immunity.

However, the view that immature DC induce tolerance and mature DC induce immunity is simplified. It has been demonstrated that mature DC can contribute to $\mathrm{T}$ cell tolerance through the induction of Treg [50]. It was suggested that it is the maturation trigger that dictates the DC's T cell polarizing or tolerating immune functions. Some triggers have been demonstrated to promote production of cytokines, such as IL-12 and IFN- $a$, hence inducing Th 1 responses. These include molecules derived from bacterial or viral products, such as LPS, CpG motifs and dsRNA, pro-inflammatory cytokines, such as tumour necrosis factor$a$ (TNF-a) and IFN-a, as well as T cell signals, mainly the interaction of CD40Ligand expressed on $\mathrm{CD}^{+}$Th cells with CD40 expressed on DC [51]. By contrast, antiinflammatory molecules, such as IL-10 and prostaglandin $\mathrm{E}_{2}$ (PGE2) hamper full DC maturation and cytokine production, thus resulting in the stimulation of Treg responses [28].

In summary, instruction of adaptive immunity occurs largely through triggering the maturation of DC. When appropriately activated immature DC transform from highly phagocytic, tissue-resident cells into highly immunogenic, lymph node-homing cells that are competent to induce $\mathrm{T}$ cell responses to non-self antigens acquired in the periphery.

\section{Activation in View Of Tumour Immunology: A Role for TLR}

As mentioned in the general introduction, immune tolerance represents a major barrier in the induction of effective cellular anti-tumour immune responses. This can be explained by the fact that tumour cells arise endogenously and that most TAA are therefore recognized as self. As a consequence, many $\mathrm{T}$ cells of the tumour-specific $\mathrm{T}$ cell repertoire have been eliminated centrally or peripherally [52]. Additionally, tumour cells have acquired several mechanisms to suppress $T$ cells that have escaped this selection. These include antigen presentation in the absence of co-stimulation, expression of inhibitory/death inducing signals (e.g. PD-L1, FasL), expression of immunomodulatory enzymes (e.g. indoleamine-2,3deoxygenase) and secretion of immune suppressive cytokines and chemokines (e.g. IL-10, transforming growth factor- $\beta$ (TGF- $\beta$ ) [53].

Moreover, these secreted inhibitory factors not only suppress effector T cells, but also promote the existence of immune cells with suppressive functions, such as Treg, regulatory DC (DCreg) and myeloid-derived suppressor cells [54, 55]. In Fig. (1), the different mechanisms of anti-tumour immunity and tumour-induced suppression mentioned throughout the introduction are summarized (Fig. 1).

One of the paradigms of immunology is that a productive $\mathrm{T}$ cell immune response requires specific recognition of an MHC/peptide complex by the TCR (signal 1) along with adequate signalling through co-stimulatory molecules (signal 2). Recently, data indicate that to establish strong anti-tumour responses, an inflammatory environment (signal 3) is required alongside functional recognition of $\mathrm{T}$ cells by antigen-presenting cells. This can be achieved by strong activation of the innate arm of the immune system, in particular through TLR. The critical roles of TLR in activation of adaptive immune responses have been well documented and extensively reviewed by [24, 56-58]. In summary, TLR have been shown to control 
adaptive immune responses at multiple levels, including the control of antigen uptake, through the remodelling of the actin cytoskeleton, resulting in uptake of antigens via macropinocytosis [59].

Furthermore, it was demonstrated that the efficiency of presenting antigens from phagocytosed cargo is dependent on the presence of TLR ligands within the cargo. Blander et al. demonstrated that the generation of peptide/MHC class II complexes is controlled by TLR in a strictly phagosome-autonomous manner. The enhanced rate of phagolysosomal maturation in the presence of signals from TLR2 and TLR4 has been clearly demonstrated [60-62]. Thus, antigen sampling by DC is controlled by TLR and the engagement of TLR signalling helps DC to distinguish between cargo containing self or non-self antigens, a property that can be exploited to induce anti-tumour immune responses. These TLR further control the maturation of DC, including their capacity to migrate, the up-regulation of the co-stimulatory molecules CD40, CD80, CD86 and CD70 and production of primarily Th 1 cytokines like IL-1, IL-6, TNF- $a$ and IL-12. The very fact that protective Th 1 cytokine response can be achieved by using TLR signalling is another interesting property in terms of anti-tumour immune responses [24, 56, 63]. Yang et al. showed that in order to break tolerance of tumour-specific CTL, persistent TLR ligation should be provided alongside antigen-loaded mature DC [64]. Similarly, Lang et al. showed that even in a transgenic mouse model where the antigen is highly expressed in the target organ (in this case the pancreas) adoptively transferred CTL were not able to actually lyse the target cells. Only concomitant TLR ligand administration induced frank diabetes [65]. Besides a lack of sufficient stimulation to break tolerance, several inhibitory mechanisms, such as the presence of Treg need to be overcome. In mouse studies, it has been shown that depletion of these Treg greatly enhances the anti-tumour response [66, 67]. Again, signalling through certain combinations of TLR on DC not only provided a synergy with respect to the production of cytokines such as IL-12 [68, 69], but also offers protection from Treg inhibition [70]. From these data it is clear that the engagement of TLR signalling pathways is a promising mechanism for boosting DC-based vaccine responses.

\section{MECHANISMS OF TLR-SIGNALLING}

Understanding the mechanism of TLR signalling and its correlated feedback mechanisms is pivotal to the exploitation of these pathways for the pill-pose of enhancing DC-based vaccines. Binding of TLR to their ligands, usually bacterial or viral-derived proteins and nucleic acids trigger a complex network of signalling molecules and adaptor proteins that will ultimately modulate DC responses in innate and adaptive immunity [24, 71, 72]. All these signalling networks cooperate, integrate and finally converge into a few pathways, such as that of mitogen-activated protein kinase (MAPK) and nuclear factor- $\mathrm{\kappa B}$ (NF- $\mathrm{\kappa B}$ ) [72-76]. In addition, these pathways interact with each other [77, 78]. It is this crosstalk together with the strength, timing and context of stimulation that determines the type and duration of immune responses [79-81]. The MAPK and NF- $\kappa$ B pathway are schematically represented in Fig. 2 and will be discussed in more detail in the following sections.

\section{Activation of MAPK Pathways in DC}

MAPK are a diverse group of intracellular serine/threonine kinases firstly discovered in yeast. They are phylogenetically conserved and regulate a wide range of cellular processes ranging from cell growth, differentiation and survival to cellular stress and immune responses [82]. Three groups of MAPK have been identified: the extracellular signalregulated protein kinases (ERK) [83, 84], the c-Jun N-terminal kinases (JNK) [85, 86] and the p38 stress-activated protein kinases (p38) $[87,88]$. They are structurally related and their catalytic core is blocked by a conserved activation loop [89]. Phosphorylation of the activation loop unblocks the catalytic site leading to phosphorylation of specific targets. 
Generally, MAPK activation starts at cellular membranes (plasma membrane or in intracellular organelles) after the engagement of receptors to their ligands. MAPK pathways consist on a three-modular cascade involving activating phosphorylations of downstream kinases by upstream kinases. In this way, MAPK kinase kinases (MAPKKK) are firstly activated by phosphorylation after their recruitment to the cytoplasmic domain of receptors through multi-protein complexes. These phosphorylated MAPKKK subsequently phosphorylate MAPK kinases (MAPKK), which in turn will phosphorylate MAPK.

In DC, MAPK are always activated after signal transduction from TLR. TLR are integral membrane proteins with an extracellular domain that binds to molecular patterns, a single transmembrane domain and a cytoplasmic domain. The TLR cytoplasmic tail contains the Toll/IL-1 receptor (TIR) domain, essential for signal transduction [90]. Simplifying, mainly (but not exclusively) two TIR-domain adaptor molecules, MyD88 (myeloid differentiation factor 88) and TRIF (Toll/IL-1 receptor domain-containing adaptor-inducing IFN- $\beta$ ) are recruited to the TLR TIR domain. Then, MAPKKK are activated through further recruitment of various protein kinases and scaffold proteins, such as ubiquitin ligases TNFRassociated factor 6 (TRAF6) and TRAF3 [91]. MAPK activation has been shown to depend on MyD88-TRAF6-mediated recruitment of a complex containing MAPKKK TAK1 (transforming growth factor-beta-activated kinase-1) [92], but also in an alternative pathway involving TRIF-TRAF3 [91]. However, there might be other pathways leading to MAPK activation depending on the cell type or the type of stimulus. As an example, Ubc13 E2 ubiquitin-conjugated protein has been shown to regulate MAPK signalling through IKK $\gamma$ binding in B cells, independently of TRAF6-TAK1 [93].

\section{The MAPK ERK Pathway}

The extracellular signal-related kinase (ERK) comprises at least 8 isoforms from which ERK1 and ERK2 are the most extensively studied. The classical ERK activation pathway starts with the binding of growth factors to cell membrane receptors such as epidermal growth factor receptor (EGFR) [94]. This results in Ras activation and association to the MAPKKK Raf-1. Raf-1 subsequently phosphorylates MAPKK, MEK1 and MEK2 (MEK1/2), which in turn phosphorylate ERK1/2 threonine and tyrosine residues at its activation loop. In fact, there is evidence that Raf-1 plays an important role in LPSdependent ERK activation during DC maturation [95]. However, this study was performed in an immortalised murine DC2.4 cell line and it does not rule out the possibility of Raf-1 phosphorylation by MEK1 through a positive feedback mechanism [96]. In the context of TLR-dependent ERK activation, TAK1 plays a prominent role [97]. However, ERK phosphorylation was not completely abrogated in cells lacking TAK1 [92], suggesting additional TLR-associated pathways leading to ERK phosphorylation. Classical ERK targets range from kinases such as 40S ribosomal protein S6 kinase (RSK) to transcription factors such as c-myc, cFos, ATF-2, Elk-1, Ets-1 and c-Jun just to name a few [98].

In DC, ERK is involved in cell survival [73], in regulation of inflammation and immune suppression [99, 100]. In fact, ERK negatively regulates DC maturation through secretion of immunosuppressive cytokines such as IL-10 and TGF- $\beta$ [76, 77, 99-105]. As already mentioned above, ERK is virtually activated by signalling through all TLR through TRAF6TAK1 and TRAF3, although it is preferentially activated by specific TLR such as TLR2 which promotes immune suppression and tolerance $[75,103,105]$ or by other TLR depending on the cell type and stimulation context [71, 106, 107].

Actually, inhibition of ERK phosphorylation with specific MEK inhibitors PD98059 and U0126 enhances DC maturation, increases pro-inflammatory cytokine secretion and counteracts tumour-induced immune suppression [101, 108-110]. Consequently, it is tempting to speculate that some kinase inhibitors used in cancer chemotherapy [111] could 
be effective immune stimulators by ERK inhibition in antigen-presenting cells. In fact, the tyrosine kinase inhibitor sunitinib, widely used in the treatment of metastatic renal cancer among others, enhances anti-tumour immune responses by decreasing numbers of myeloidderived suppressor cells and Treg [112]. However, in this particular case, immune activation was linked to inhibition of STAT3 phosphorylation, although some ERK inhibition was observed [113].

\section{The MAPK p38 Pathway}

MAPK p38 comprises at least four splice isoforms from which p38a and p38 $\beta$ are ubiquitously expressed. In the context of TLR activation, p38 phosphorylation is completely dependent on TAK1 activity as shown in embryonic fibroblasts and B cells [92]. In fact, it has been shown that TAK1 phosphorylates MKK3 and MKK6, the two main p38 MAPKK $[114,115]$. In turn, MKK3 and MKK6 phosphorylate $\mathrm{p} 38$ within its activation loop. Classical p38 targets range from kinases such as MK2 and transcription factors such as ATF, $\mathrm{p} 53, \mathrm{c} / \mathrm{EBP} \beta$ and NFAT just to mention a few [116].

MAPK p38 plays an important part in DC maturation and secretion of pro-inflammatory cytokines. Therefore, it is not surprising that $\mathrm{p} 38$ inhibition is one of the most frequent strategies for the treatment of auto-immune and inflammatory diseases [111]. In fact, LPS and TNF-a-dependent up-regulation of DC co-stimulatory molecules and maturation markers such as CD40, CD80, CD86, CD83 and MHC class II is inhibited by SB203580, a specific p38 inhibitor [117]. Combined evidence from p38 specific inhibitors and KO mice has shown that the p38 pathway is involved in secretion of IL- $1 \beta$, TNF- $a$, IL- 6 and IL-12 [117-119]. Accordingly, LPS-induced $\mathrm{p} 38$ activity could up-regulate transcription of cytokine genes by ATF2 and CREB phosphorylation [82, 120]. However, there is evidence that p38 activity on its own does not up-regulate pro-inflammatory cytokine genes [100, 121]. In fact, $\mathrm{p} 38$ induces changes in chromatin structure that allow NF- $\mathrm{kB}$ to bind to cytokine promoters leading to their transcriptional transactivation [121].

Remarkably, MAPK p38 and ERK play antagonistic effects in many cell types, including antigen-presenting cells such as macrophages and DC [101]. There is growing evidence that ERK and $\mathrm{p} 38$ regulation is interconnected by several mechanisms. In macrophages, TGF- $\beta$ activated ERK up-regulates MAPK phosphatase 1 (MKP1) that eventually dephosphorylates p38 [122]. In some cases, p38 stimulates phosphatase PP2A activity, leading to MEK1/2 dephosphorylation [98, 123]. In zymosan-stimulated splenic DC, ERK leads to p38 dephosphorylation through up-regulation of suppressor of cytokine signalling 3 (SOCS3) [105]. Moreover, direct interactions between ERK and p38 have been reported, adding a potential regulatory level in both MAPK pathways [124].

\section{The MAPK JNK Pathway}

c-Jun N-terminal kinase (JNK) proteins are encoded by 3 genes with 10 or more alternative splice forms [125]. From these, the JNK1 and JNK2 isoforms are the most extensively studied. JNK is activated by UV irradiation, environmental and chemical stress, proinflammatory cytokines and TLR signalling [91, 97, 114, 125]. JNK activation relies on its dual phosphorylation of threonine and tyrosine residues by MAPKK, MKK4 and MKK7. The classical JNK targets are c-Jun, from which it receives its name, ATF2, p53, Elk-1 and c-Myc amongst others $[98,120,125,126]$.

ATF2 and c-Jun are components of AP-1, a transcription factor that transactivates many proinflammatory genes. Consequently, JNK is involved in inflammatory responses and inhibitors are being evaluated in clinical trials for the treatment of autoimmune diseases such 
as rheumatoid arthritis as well as asthma, inflammatory diseases and some types of leukaemia [111].

In the context of TLR signalling, TAK1 is involved in JNK activation through MKK3 and MKK7 phosphorylation [92, 97, 114, 127]. In general, JNK activity enhances DC maturation and pro-inflammatory cytokine secretion, although at lower levels compared to p38 [100, 128]. Treatment of DC with the specific JNK inhibitor SP600125 decreased LPSinduced c-Jun phosphorylation, inhibited TNF- $a$ and IL-12 secretion and slightly inhibited up-regulation of co-stimulatory molecules CD80, CD86, CD83 and ICAM-I [128]. Therefore, JNK has been considered as a cooperative pathway together with NF- $\mathrm{kB}$ and $\mathrm{p} 38$, rather than playing a central role in DC maturation.

\section{The NF-kB Pathway in DC}

NF- $\kappa$ B was first identified in 1986 as a transcription factor that binds to a 10 base pair DNA element, consensus sequence $5^{\prime}$-GGGAATTTCC- $3^{\prime}$ and its many variations, in the $x$ immunoglobulin light-chain enhancer in B cells, hence its name [129].

The molecules that comprise the NF- $x \mathrm{~B}$ family have been shown to be central to immunity and inflammation [130]. Their importance in DC biology has been demonstrated by the many DC-related defects in NF- $\mathrm{kB}$ KO mice [131-136].

The NF- $\mathrm{kB}$ family members exist as homo- or heterodimeric complexes formed by combinations of five distinct DNA binding subunits, p65/RelA, RelB, c-Rel, p50 and p52. Of these, RelA, RelB and c-Rel are synthesized in their mature forms and contain a transactivation domain that interacts with the transcriptional apparatus. On the other hand, p50 and p52 are synthesized in precursor forms, which contain C-terminal ankyrin repeats that are proteolysed by the proteasome resulting in the production of mature proteins. Both p50 and p52 contain a DNA binding domain, but lack a transactivation domain. It is noteworthy that in particular RelB has been implicated in the differentiation and maturation of DC. RelB-deficient mice lack mature myeloid DC $[132,137]$. Furthermore, DC in which RelB expression is inhibited retain an immature phenotype and are associated with induction of immune tolerance in vivo [138].

All the NF- $\kappa$ B proteins are characterized by the presence of a highly conserved 300 amino acid Rel homology domain that is located at the N-terminus of the protein. It is this domain that is responsible for the dimerization and subsequent DNA binding. Furthermore, this Rel homology domain interacts with specific inhibitory factors known as inhibitors of $\kappa \mathrm{B}$ (I $\kappa \mathrm{B})$ proteins. A number of different $\operatorname{I} \kappa B$ proteins exist. These are $\operatorname{I} \kappa B a, I \kappa B \beta, I \kappa B \gamma, \operatorname{I\kappa B}$ and Bcl-3. It is generally believed that the different isoforms are associated with particular Rel protein dimers, bound via their Rel homology domain. For example I $\mathrm{B} B a$ and $I \kappa B \beta$ associate with RelA/p50 and p50/c-Rel, whereas I $\mathrm{B}$ only binds to RelA and c-Rel heteroand homodimers. The binding of I $\kappa \mathrm{B}$ to these dimers keeps these NF- $\kappa \mathrm{B}$ dimers in an inactive state, mainly in the cytosol. The NF- $\kappa \mathrm{B} / \mathrm{I} \kappa \mathrm{B}$ complex can shuttle between the cytoplasm and the nucleus in unstimulated cells, but nuclear export of the complex is inefficient and therefore, the NF- $\mathrm{kB} / \mathrm{I} \kappa \mathrm{B}$ complex is mainly cytoplasmic in resting cells.

NF- $\kappa B$ can be activated by many divergent stimuli, including pro-inflammatory cytokines (such as TNF-a, IL-1), T cell delivered signalling (CD40L), bacteria, viruses and cellular stress (such as UV, ionizing radiation and chemotherapeutic agents), signals that mediate DC maturation [139]. Different NF- $\mathrm{kB}$ activation pathways have been described [140, 141]. Essentially, these pathways share adaptor molecules with the above-described MAPK pathways and can basically be divided into a classical (canonical) and non-classical pathway $[140,142,143]$. Both pathways start a chain reaction of events resulting in the activation of 
I $\times$ B kinases (IKK), which stimulate the phosphorylation and ubiquitination-induced degradation of $\mathrm{I} \kappa \mathrm{B}$, as such releasing an active form of NF- $\kappa \mathrm{B}$.

I $\mathrm{kB}$ kinase (IKK) is a multi-subunit protein kinase consisting of two highly homologous catalytic subunits, IKKa and IKK $\beta$, which phosphorylate I $\times$ B and a non-enzymatic regulatory subunit, IKK $\gamma$ (also called NEMO, NF- $\kappa \mathrm{B}$ essential modulator), which is required for the activation of IKKa/IKK $\beta$ heterodimers in response to pro-inflammatory cytokines, such as TNF- $\alpha$ and IL-1 [144-146]. Phosphorylation of I $\kappa$ B at two critical serine residues (Ser32/Ser36 in I $\mathrm{BBa}$ and Ser19/Ser23 in I BB $\beta$ ) in their N-terminal regulatory domain by the IKK complex targets them for rapid polyubiquitination and subsequent degradation by the $26 \mathrm{~S}$ proteasome [147]. This IKB isoform phosphorylation is stimulus specific, for example I $\mathrm{KB} \beta$ is only phosphorylated by certain stimuli including LPS and IL-1 $\beta$, whereas most NF- $\kappa$ B activators trigger I $\kappa \mathrm{Ba}$ phosphorylation. This level of control is also thought to impact on the cell type specificity and kinetics of the response, which in turn can influence the duration of transcription.

In the classical pathway, it has been shown that IKK®, but not IKKa, is important in NF$\kappa B$ activation. Furthermore, it has been demonstrated that these two kinases have distinct rather than overlapping functions [148-151]. The classical pathway includes signalling from TLR/IL-1R family members, intracellular pattern recognition receptors including retinoic acid inducible gene (RIG-I), melanoma differentiation associated factor-5 (MDA-5) and protein kinase R (PKR), as well as signalling from the TNFR (reviewed by [152]). Mediators such as lymphotoxin- $\beta, \mathrm{CD} 40 \mathrm{~L}$ and receptor activator of NF- $\mathrm{\kappa B}$ ligand (RANKL) activate the non-classical pathway $[153,154]$. This pathway involves IKKa phosphorylation, processing of the p52 precursor p100 and nuclear translocation of the heterodimer p52/RelB and is believed to play a key role in adaptive immunity $[155,156]$.

The NF- $\mathrm{BB}$ pathway is further controlled by post-translation modifications, i.e. phosphorylation and acetylation. These modulate the interaction of Rel proteins with other components of the transcriptional machinery and alter their kinetics in and out of the nucleus. The phosphorylation status of NF- $\mathrm{kB}$ can influence activation, e.g. phosphorylation of RelA may enhance transcriptional activation. On the other hand phosphorylation of the p50 precursor p105 can reduce its processing into p50 [157]. NF- $\mathrm{kB}$ can also associate with other transcriptional proteins such as histone acetyltransferase and histone deacetylase (reviewed by [158]). Acetylation of the Rel proteins can increase the time it is located in the nucleus [159]. Furthermore recent data suggest that the phosphorylation and acetylation steps occur stepwise, phosphorylation of RelA is required prior to and enhances acetylation of Rel A in order to improve transcriptional activity of NF- $\mathrm{kB}$ [160].

As mentioned above, NF- $\kappa$ B targets different genes, encoding proteins that are associated with mature DC, amongst these are cytokines (e.g. IL-6, IL-12, TNF-a), chemokines (e.g. MIP-1a, MCP1), adhesion molecules (e.g. ICAM-1), inducible effector enzymes (e.g. COX-2), as well as regulators of apoptosis (e.g. c-IAP, XIAP, Bcl-xL). Since, NF- $\times B$ regulates so many different immune activation-related genes and hence controls the properties of DC, tight regulation by negative feedback is required to avoid the generation of chronic inflammatory milieu that can lead to autoimmunity. Several feedback molecules have been described, including I $\mathrm{B}$, A20 (or TNF- $\alpha$ inducible protein 3, TNFAIP3), tripartite-motif protein (TRIM) 30a and phosphatase PP2A, to name a few [161-166].

The remainder of this section will introduce A20, since A20 has been recently studied and shown to be potentially interesting in view of enhancing tumour antigen-specific immune responses. A20 was originally identified as a TNF-inducible gene in human umbilical vein endothelial cells [167]. Subsequent research demonstrated that A20 is also induced in many 
other cell types, amongst which mouse and human DC [161, 168, 169]. A20 expression is under the immediate control of NF- $\mathrm{kB}$. Therefore, it is not surprising that A20 expression is observed in response to various stimuli including TNF, IL-1 and TLR ligands [170-173]. Recently, it has been demonstrated that A20 is an ubiquitin-editing enzyme with deubiquitinase activity in the $\mathrm{N}$-terminal region and ubiquitinase activity in the zinc finger domain of the C-terminal region. It is through this dual ubiquitin-editing function of A20, that it can modulate down-regulation of NF- $\mathrm{BB}$ signalling, this through interaction with several proteins of the TNF-, IL-1/TLR-signaling pathways, amongst which TRIF, RIP, IRAK1, TRAF6, NEMO/IKK $\gamma$ and I BB-kinases [169, 170, 172, 174-177]. Similar to NF$\mathrm{B}, \mathrm{A} 20$ can be further regulated by post-translational modification. An IKK-dependent phosphorylation of A20 at Ser381 has been shown to increase the ability of A20 to inhibit NF- $\mathrm{kB}$ activation. The mechanism, however, has yet to be elucidated [178]. The role of A20 in DC will be discussed in the section 'down-regulation of feedback mechanisms'.

\section{MODIFICATION OF DC IN ORDER TO MIMIC PERSISTENT TLR SIGNALLING}

DC are considered to be the most potent antigen-presenting cells of the immune system, one of the most well-studied vaccination approaches is the use of DC loaded ex vivo or in vivo with TAA in one form or another to boost/induce anti-tumour immune responses in cancer patients. Several approaches have been studied for loading DC with antigen, the description of which is outside the scope of this review. Of these the most promising strategies introduce the genetic information of the entire tumour antigen fused to MHC class II targeting signals, hence obtaining antigen-presentation to both $\mathrm{CD} 8^{+}$and $\mathrm{CD} 4^{+} \mathrm{T}$ cells, respectively $[179,180]$. Broadly speaking, these genetic modification methods can be divided in viral and non-viral methods, which have been reviewed in [14, 181-184]. In recent years, these strategies have been employed to not only deliver TAA, but simultaneously deliver signals that result in functional modification of DC, be it the introduction of activation-inducing molecules for anti-tumour therapy or the introduction of activation inhibitors, with the purpose of inducing antigen-specific tolerance.

\section{CO-DELIVERY OF TUMOUR ANTIGEN AND CONSTITUTIVE ACTIVE TLR4 TO DC}

Both mouse and human DC express TLR4, which binds LPS (aided by CD14 and MD-2), resulting in DC maturation [185]. This is mediated by both NF- $\mathrm{kB}$ and MAPK [82, 117]. LPS-mediated activation has been shown to remarkably enhance the ability of DC to stimulate antigen-specific immune responses in vitro. Moreover, it was reported that LPSactivated DC could overcome suppression by Treg, a critical factor in anti-tumour immunology [186]. However, the clinical use of LPS for immunotherapy is prohibited due to cytotoxicity concerns as well as batch-to-batch variability. Therefore, several groups have focused on the generation and evaluation of a constitutive active TLR4 (caTLR4) for DC maturation [187-190]. Therefore, the TLR was truncated between positions M620 - P621 and linked to the nerve growth factor leader sequence $[187,189]$ or the leader sequence of LAMP1 [188]. Alternatively the cytoplasmic domain of TLR4 was linked to the extracellular single-chain immunoglobulin anti-erbB2 [190]. These caTLR4 molecules were subsequently delivered to DC under the form of mRNA, either by transfection [187, 189] or electroporation [188] or through retroviral transduction [190]. Evidence for NF- $\kappa \mathrm{B}$ activation upon introduction of caTLR4 was delivered and it was shown that DC modified with this caTLR4, either [188] or not [187, 189] in combination with CD40L, become mature. Moreover, these DC were able to stimulate CTL, specific for both the strong immunogen MelanA and the weak immunogen Trp2 [187-189]. 


\section{Co-delivery of Tumour Antigen and Activation Signals to DC}

With regard to activation of DC via TLR4, Hamdy et al. have shown that vaccination of B16 tumour bearing mice with PLGA nanoparticles co-encapsulating the poorly immunogenic melanoma antigen, TRP2, along with the TLR4 ligand, 7-acyl lipid A, has therapeutic effects [191]. With regard to co-delivery of TAA and TLR ligands in a one step modification, we have demonstrated that electroporation can be applied for the simultaneous delivery of TAA encoding mRNA and dsRNA, in particular Ampligen or poly $\left(\mathrm{I}: \mathrm{C}_{12} \mathrm{U}\right)$, which is a GMP-grade synthetic analogue of the TLR3 ligand, poly(I:C) and therefore suitable for human and more importantly clinical use $[26,161]$. This strategy resulted in upregulation of A20, thus suggesting activation of NF- $\mathrm{KB}$ [161]. Moreover, small amounts of Ampligen were sufficient to induce fully mature DC, capable of efficiently stimulating MelanA-specific immune responses [26].

Besides the delivery of these activation stimuli using non-viral strategies, it has been repeatedly shown that many of the viral vector preparations used for delivery of antigens are inherently activating DC [192-197]. It has been demonstrated that different virus types, amongst which adenovirus, lentivirus (human immunodeficiency virus and equine anaemia virus), as well as Moloney murine leukaemia virus, up-regulate co-stimulatory and antigenpresenting molecules on DC. In case of adenoviral and lentiviral vectors, it has been further shown that these induce production of Th 1 and pro-inflammatory cytokines, resulting in DC with strong $\mathrm{T}$ cell stimulatory capacity. This can be explained by the triggering of intracellular signalling pathways, such as those initiated by $2^{\prime}, 5^{\prime}$-oligoadenylate synthetases $\left(2^{\prime}, 5^{\prime}-\right.$ OAS $)$ and PKR. Furthermore, it has been demonstrated in a $293 \mathrm{~T}$ reporter assay that lentiviruses can activate several TLR $[192,193]$. Additionally, it has been shown that direct administration of lentiviral vectors results in transduction of cells at the periphery, that these cells migrate to lymphoid organs [198] and are able to stimulate antigen-specific immune responses [199-204]. The latter two observations further deliver circumstantial evidence for the capacity of lentiviral vectors to activate DC.

\section{Delivery of Signal Adaptor Molecules to DC (Fig. 3)}

DC function can effectively be modulated using gene therapy techniques by the introduction of genes that control DC differentiation and maturation. NF- $\kappa B$ has been one of the first pathways to be targeted in DC as an adjuvant strategy. In this case, NF- $\kappa B$ inducing kinase (NIK) was over-expressed using adenovirus vectors. NIK over-expression increased DC maturation as assessed by up-regulation of co-stimulatory molecules, MHC molecules and secretion of pro-inflammatory cytokines [205]. In this context, co-expression of NIK with GFP significantly increased Th1 GFP-specific immune responses, although the relevance of this strategy in anti-viral or anti-tumour immunity was not assessed [205]. Another strategy has been the introduction of MyD88, TRIF or IRAK-1, all major TLR adaptor molecules, which when over-expressed were shown to transduce downstream signals without TLR stimuli. Akazawa et al. [206] successfully introduced MyD88 and TRIF in mouse DC using lentiviral vectors, resulting in DC with different properties. MyD88-modified DC produced IL-6 and IL-12p40, but showed no up-regulation of phenotypic markers, whereas TICAM-1 introduction stimulated interferon IFN-a production and had enhanced levels of CD86. Both MyD88 and TRIF augmented the allo-stimulatory capacity of the DC. Moreover, antigenspecific responses could be efficiently induced and tumour outgrowth was delayed by immunization with these MyD88- and TRIF-modified DC [207]. Xu et al. generated retroviral vectors encoding the chimeric proteins consisting of the extracellular single-chain immunoglobulin anti-erbB2 linked to an intracellular TLR-signalling component composed of either MyD88 or IRAK-1. Their experiments were performed in the DC line, JAWS II, in which only the IRAK-1 chimera was able to mediate IL-12 and TNF-a secretion. The latter was subsequently, evaluated for its capacity to enhance the T cell stimulatory capacity of 
DC, demonstrating enhanced ovalbumin-specific OT-II CD4 ${ }^{+}$T cell responses [190]. A fourth study targeted NF- $\mathrm{\kappa B}$ activation in DC using lentiviral vectors, by expressing Kaposi's sarcoma associated human herpes virus (KSHV) vFLIP [208]. In this case, DC maturation was enhanced by up-regulation of MHC I and II, co-stimulatory molecules CD80, CD86, CD40 and ICAM-I. In addition, increased antigen-specific CD8 ${ }^{+} \mathrm{T}$ cell responses and expression of TNF- $\alpha$ and IL-12 was achieved and an enhanced anti-tumour and anti-parasite immunity were demonstrated [208, 209].

As already discussed, another group of signalling pathways with a critical role in DC function is the MAPK family. MAPK pathways regulate DC maturation and modulate the type of immune response in concert with NF- $\mathrm{kB}$ and other pathways. Therefore, the specific delivery of antigen with modulators of MAPK pathways to DC could enhance antigenspecific immune responses or induce antigen-specific immune suppression. Additionally, activation of individual MAPK pathways in the absence of TLR stimulation could dissect the specific role of each individual pathway in DC function. This could potentially lead to a fine-tuning of DC-dependent immune responses. MAPK have been recently targeted in DC using LV, by expression of selected constitutive activated mutants of the three main MAPK pathways [100].

MAPK ERK and p38 were activated by expressing MEK1 and MKK6 mutants containing glutamate and aspartate residues in their activation loop, mimicking activating phosphorylated serine or threonine residues [210]. A fusion protein between MKK7 and JNK1 was expressed to achieve constitutive JNK1 phosphorylation [211]. In addition, expression of constitutive activators prevents inactivation by negative feedback mechanisms such as MAPK phosphatase activities, which may be important to counteract tolerogenic mechanisms in anti-tumour immunity. In the absence of TLR stimulation, p38 activation resulted in a DC maturation phenotype different from full maturation as achieved by LPS treatment [100]. No specific effects on MHC levels or CD86 were observed. On the other hand, there was specific up-regulation of CD80, CD40 and ICAM-I. Additionally, no significant secretion of pro-inflammatory cytokines IL-12, TNF- $\alpha$, IL-1 $\beta$ or IL-23 was detected [100], in contrast to studies using p38 inhibitors in the context of TLR stimulation [117-119].

Therefore, p38 activation would not be directly involved in transcriptional up-regulation of cytokine genes, as suggested by other studies [121]. Interestingly, co-expression of OVA with the p38 activator in DC significantly increased antigen-specific $\mathrm{CD} 4^{+}$and $\mathrm{CD} 8^{+} \mathrm{T}$ cell responses leading to increased anti-tumour immunity [100, 209]. MAPK p38 constitutive activation also increased $\mathrm{CD} 8^{+} \mathrm{T}$ cell responses to human tumour antigens NY-ESO in an HLA-A2 humanised transgenic mouse model, and MelanA/MART-1 in a human DC-T cell culture [100].

Specific activation of JNK1 in DC showed only a moderate up-regulation of CD80 and ICAM-I and no significant secretion of pro-inflammatory cytokines. These results confirmed previous studies with inhibitors showing that in comparison with $\mathrm{p} 38$, JNK marginally control DC maturation $[100,128]$. Nevertheless, increased antigen-specific CD8 ${ }^{+} \mathrm{T}$ cell responses were detected after subcutaneous vaccination with LV expressing MKK7-JNK1, suggesting that JNK1 may play a subtle but still important role in DC in vivo [100].

In the absence of TLR stimulation, constitutive ERK activation in DC resulted in an immature phenotype with down-regulated CD40 and increased TGF- $\beta$ expression [100]. Curiously, in contrast to abundant published literature on the subject, ERK constitutive activation did not induce IL-10 secretion [76, 77, 99-105]. This situation may be analogous to that of p38 and IL-12 secretion. ERK activation may be important but not sufficient for 
high-level secretion of IL-10. Interestingly, co-expression of the ERK activator with an OVA transgene in DC led to impaired OVA-specific $\mathrm{CD} 4^{+}$and $\mathrm{CD} 8^{+} \mathrm{T}$ cell responses and systemic increase in Foxp3 Treg [100]. Therefore, constitutive activation of ERK in the absence of TLR stimulation can effectively suppress antigen-specific immune responses.

\section{DOWN-REGULATION OF FEEDBACK MECHANISMS}

As mentioned above, A20 is one of the feedback regulators of NF- $\kappa$ B. A20 shares some similarities with $\mathrm{I} \kappa \mathrm{Ba}$, another feedback regulator. For one, the expression of both is controlled by NF- $\kappa$ B and shows similar temporal profiles [212]. However, I $\kappa \mathrm{Ba}$ directly inhibits NF- $\kappa$ B, while A20 functions upstream to deactivate several adaptor molecules of the TNFR, IL-1/TLR signalling through its ubiquitinating/de-ubiquitinating properties. In this way, A20 controls IKK and thus the degradation of I $\mathrm{Ka}$. Recent studies demonstrate that A20 is expressed in mouse DC activated with LPS (TLR4) [168], as well as in human DC activated with poly(I:C) or through electroporation with its clinically acceptable analogue, Ampligen [161]. This led to the hypothesis that down-regulation of A20 would result in prolonged NF- $\kappa$ B activation, hence mimicking persistent TLR ligation and as such resulting in DC with enhanced stimulatory capacity. RNA interference through introduction of a lentivirally delivered shRNA or through introduction of siRNA, respectively, was applied to down-regulate A20 [161, 168]. Both Song et al. and we demonstrated that A20 plays a crucial part in controlling the maturation, cytokine production and immunostimulatory potency of the DC [168]. While, we focused on the expression pattern of NF- $\kappa \mathrm{B}$, the secretion of cytokines, in particular IL-10 and IL-12 and their role in stimulation of MelanA-specific T cells, Song et al. focused on the ability of the DC to stimulate antigen-specific CTL and the effect of Treg on both DC and effector T cells.

In summary, human DC with down-regulated A20 expression have higher levels of NF- $\kappa \mathrm{B}$ and show enhanced and sustained secretion of both IL-10 and IL-12. IL-10 was shown to negatively influence T cell proliferation, whereas IL-12 had an impact on Th 1 cell induction. In general these DC were more potent in the stimulation of MelanA-specific $\mathrm{CD}^{+} \mathrm{T}$ cells [161]. Mouse DC with down-regulated A20 expression showed spontaneous and enhanced expression of co-stimulatory molecules and pro-inflammatory cytokines, where refractory to Treg inhibition and activated tumour-infiltrating CTL and Th cells that in turn were unresponsive to Treg mediated suppression [168]. These studies identify A20 as an antigen-presentation attenuator and an ideal target in view of anti-tumour immunotherapy, since it not only enables the DC to induce strong effector $\mathrm{T}$ cell responses and it suppresses the suppressors, the Treg.

\section{FUTURE PERSPECTIVES}

DC play a crucial role in regulating both innate and adaptive immunity. Accordingly, DC present many pathogen recognition receptors such as TLR that enable them to detect potential threats such as viruses and bacteria. TLR engagement leads to the activation of NF$\kappa \mathrm{B}$ and MAPK through MyD88 and TRIF-dependent pathways in a series of down-stream kinase cascades. The implication of each MAPK pathway in DC function and immunity has been extensively characterised by the use of specific MAPK inhibitors and by single activation of MAPK pathways. In this way, MAPK p38 plays a major role in regulating inflammatory immune responses, leading to increased immunisation, while JNK pathways play a secondary role (although probably important in vivo). ERK activity is linked to secretion of suppressive cytokines IL-10 and TGF- $\beta$ and its activity is clearly linked to immune suppression and tolerance. On the other hand NF- $\kappa \mathrm{B}$, a transcription factor that can be induced upon stimulation with a variety of different stimuli, has always been associated with maturation of DC and their capacity to stimulate potent $\mathrm{T}$ cell responses, as well as to 
overcome Treg, hence with immune activation. Finally, NF- кB and MAPK pathways can be modulated in DC by gene therapy techniques, leading to either immune activation and increased immunity, or immune suppression and tolerance.

\section{Acknowledgments}

Karine Breckpot is funded by the Fund for Scientific Research-Flanders (FWO-Vlaanderen). David Escors is funded by an Arthritis Research Campaign Career Development Fellowship.

\section{ABBREVIATIONS}

$\begin{array}{ll}\text { DC } & \text { Dendritic cell } \\ \text { TAA } & \text { Tumour associated antigen } \\ \text { Th } & \text { T helper } \\ \text { IL } & \text { Interleukin } \\ \text { Treg } & \text { Regulatory T cell } \\ \text { DCreg } & \text { Regulatory DC } \\ \text { CTL } & \text { Cytolytic T lymphocyte } \\ \text { TLR } & \text { Toll like receptor }\end{array}$

\section{REFERENCES}

[1]. Shaw GB. The Doctor's Dilemma. Int. J. Epidemiol. 2003; 32:910-915. [PubMed: 14681241]

[2]. Ehrlich P. Ueber den jetzigen Stand der Karzinomforschung. Ned. Tijdschr. Geneesk. 1909; 5:273-290.

[3]. Mak TW. The T cell antigen receptor: "The Hunting of the Snark". Eur. J. Immunol. 2007; 37:S83-S93. [PubMed: 17972349]

[4]. Burnet FM. The concept of immunological surveillance. Prog. Exp. Tumor Res. 1970; 13:1-27. [PubMed: 4921480]

[5]. Boon T, van der Bruggen P. Human tumor antigens recognized by T. lymphocytes. J. Exp. Med. 1996; 183:725-729. [PubMed: 8642276]

[6]. Van den Eynde BJ, van der Bruggen P. T cell defined tumor antigens. Curr. Opin. Immunol. 1997; 9:684-693. [PubMed: 9368778]

[7]. Pittet MJ, Mempel TR. Regulation of T-cell migration and effector functions: insights from in vivo imaging studies. Immunol. Rev. 2008; 221:107-129. [PubMed: 18275478]

[8]. Lurquin C, Lethe B, De Plaen E, Corbiere V, Theate I, van Baren N, Coulie PG, Boon T. Contrasting frequencies of antitumor and anti-vaccine $\mathrm{T}$ cells in metastases of a melanoma patient vaccinated with a MAGE tumor antigen. J. Exp. Med. 2005; 201:249-257. [PubMed: 15657294]

[9]. Gattinoni L, Powell DJ Jr. Rosenberg SA, Restifo NP. Adoptive immunotherapy for cancer: building on success. Nat. Rev. Immunol. 2006; 6:383-393. [PubMed: 16622476]

[10]. Tuyaerts S, Aerts JL, Corthals J, Neyns B, Heirman C, Breckpot K, Thielemans K, Bonehill A. Current approaches in dendritic cell generation and future implications for cancer immunotherapy. Cancer Immunol. Immunother. 2007; 56:1513-1537. [PubMed: 17503040]

[11]. Steinman RM, Cohn ZA. Identification of a novel cell type in peripheral lymphoid organs of mice. I: morphology, quantitation, tissue distribution. J. Exp. Med. 1973; 137:1142-1162. [PubMed: 4573839]

[12]. Young JW, Steinman RM. The hematopoietic development of dendritic cells: a distinct pathway for myeloid differentiation. Stem Cells. 1996; 14:376-387. [PubMed: 8843539] 
[13]. Steinman RM. Some interfaces of dendritic cell biology. APMIS. 2003; 111:675-697. [PubMed: 12974772]

[14]. Breckpot K, Heirman C, Neyns B, Thielemans K. Exploiting dendritic cells for cancer immunotherapy: genetic modification of dendritic cells. J. Gene Med. 2004; 6:1175-1188. [PubMed: 15468193]

[15]. Steinman RM. Dendritic cells: understanding immunogenicity. Eur. J. Immunol. 2007; 37:S53S60. [PubMed: 17972346]

[16]. Ueno H, Klechevsky E, Morita R, Aspord C, Cao T, Matsui T, Di Pucchio T, Connolly J, Fay JW, Pascual V, Palucka AK, Banchereau J. Dendritic cell subsets in health and disease. Immunol. Rev. 2007; 219:118-142. [PubMed: 17850486]

[17]. O'Keeffe M, Hochrein H, Vremec D, Caminschi I, Miller JL, Anders EM, Wu L, Lahoud MH, Henri S, Scott B, Hertzog P, Tatarczuch L, Shortman K. Mouse plasmacytoid cells: long-lived cells, heterogeneous in surface phenotype and function, that differentiate into CD8(+) dendritic cells only after microbial stimulus. J. Exp. Med. 2002; 196:1307-1319. [PubMed: 12438422]

[18]. Fitzgerald-Bocarsly P, Dai J, Singh S. Plasmacytoid dendritic cells and type I IFN: 50 years of convergent history. Cytokine Growth Factor Rev. 2008; 19:3-19. [PubMed: 18248767]

[19]. Dzionek A, Sohma Y, Nagafune J, Cella M, Colonna M, Facchetti F, Gunther G, Johnston I, Lanzavecchia A, Nagasaka T, Okada T, Vermi W, Winkels G, Yamamoto T, Zysk M, Yamaguchi Y, Schmitz J. BDCA-2, a novel plasmacytoid dendritic cell-specific type II C-type lectin, mediates antigen capture and is a potent inhibitor of interferon alpha/beta induction. $\mathrm{J}$. Exp. Med. 2001; 194:1823-1834. [PubMed: 11748283]

[20]. Grouard G, Rissoan MC, Filgueira L, Durand I, Banchereau J, Liu YJ. The enigmatic plasmacytoid T cells develop into dendritic cells with interleukin (IL)-3 and CD40-ligand. J. Exp. Med. 1997; 185:1101-1111. [PubMed: 9091583]

[21]. Bauer M, Redecke V, Ellwart JW, Scherer B, Kremer JP, Wagner H, Lipford GB. Bacterial CpGDNA triggers activation and maturation of human CD11c-, CD123+ dendritic cells. J. Immunol. 2001; 166:5000-5007. [PubMed: 11290780]

[22]. Gilliet M, Boonstra A, Paturel C, Antonenko S, Xu XL, Trinchieri G, O’Garra A, Liu YJ. The development of murine plasmacytoid dendritic cell precursors is differentially regulated by FLT3-ligand and granulocyte/macrophage colony-stimulating factor. J. Exp. Med. 2002; 195:953-958. [PubMed: 11927638]

[23]. Robinson SP, Patterson S, English N, Davies D, Knight SC, Reid CD. Human peripheral blood contains two distinct lineages of dendritic cells. Eur. J. Immunol. 1999; 29:2769-2778. [PubMed: $10508251]$

[24]. van Duin D, Medzhitov R, Shaw AC. Triggering TLR signaling in vaccination. Trends Immunol. 2006; 27:49-55. [PubMed: 16310411]

[25]. Krug A, Towarowski A, Britsch S, Rothenfusser S, Hornung V, Bals R, Giese T, Engelmann H, Endres S, Krieg AM, Hartmann G. Toll-like receptor expression reveals CpG DNA as a unique microbial stimulus for plasmacytoid dendritic cells which synergizes with CD40 ligand to induce high amounts of IL-12. Eur. J. Immunol. 2001; 31:3026-3037. [PubMed: 11592079]

[26]. Michiels A, Breckpot K, Corthals J, Tuyaerts S, Bonehill A, Heirman C, Thielemans K, Aerts JL. Induction of antigen-specific CD8+ cytotoxic T cells by dendritic cells co-electroporated with a dsRNA analogue and tumor antigen mRNA. Gene Ther. 2006; 13:1027-1036. [PubMed: 16511519]

[27]. Breckpot K, Corthals J, Bonehill A, Michiels A, Tuyaerts S, Aerts C, Heirman C, Thielemans K. Dendritic cells differentiated in the presence of IFN-\{beta $\}$ and IL-3 are potent inducers of an antigen-specific CD8+ T cell response. J. Leukoc. Biol. 2005; 78:898-908. [PubMed: 16037410]

[28]. Jonuleit H, Schmitt E, Steinbrink K, Enk AH. Dendritic cells as a tool to induce anergic and regulatory T cells. Trends Immunol. 2001; 22:394-400. [PubMed: 11429324]

[29]. Mahnke K, Schmitt E, Bonifaz L, Enk AH, Jonuleit H. Immature, but not inactive: the tolerogenic function of immature dendritic cells. Immunol. Cell Biol. 2002; 80:477-483. [PubMed: 12225384]

[30]. Martin P, Del Hoyo GM, Anjuere F, Arias CF, Vargas HH, Fernandez LA, Parrillas V, Ardavin C. Characterization of a new subpopulation of mouse CD8alpha+ B220+ dendritic cells endowed 
with type 1 interferon production capacity and tolerogenic potential. Blood. 2002; 100:383-390. [PubMed: 12091326]

[31]. Cerundolo V, Hermans IF, Salio M. Dendritic cells: a journey from laboratory to clinic. Nat. Immunol. 2004; 5:7-10. [PubMed: 14699398]

[32]. Salio M, Palmowski MJ, Atzberger A, Hermans IF, Cerundolo V. CpG-matured murine plasmacytoid dendritic cells are capable of in vivo priming of functional CD8 T cell responses to endogenous but not exogenous antigens. J. Exp. Med. 2004; 199:567-579. [PubMed: 14970182]

[33]. Salio M, Cella M, Vermi W, Facchetti F, Palmowski MJ, Smith CL, Shepherd D, Colonna M, Cerundolo V. Plasmacytoid dendritic cells prime IFN-gamma-secreting melanoma-specific CD8 lymphocytes and are found in primary melanoma lesions. Eur. J. Immunol. 2003; 33:1052-1062. [PubMed: 12672071]

[34]. Wilson NS, El-Sukkari D, Villadangos JA. Dendritic cells constitutively present self antigens in their immature state in vivo and regulate antigen presentation by controlling the rates of MHC class II synthesis and endocytosis. Blood. 2004; 103:2187-2195. [PubMed: 14604956]

[35]. Lutz MB, Schuler G. Immature, semi-mature and fully mature dendritic cells: which signals induce tolerance or immunity? Trends Immunol. 2002; 23:445-449. [PubMed: 12200066]

[36]. Steinbrink K, Wolfl M, Jonuleit H, Knop J, Enk AH. Induction of tolerance by IL-10-treated dendritic cells. J. Immunol. 1997; 159:4772-4780. [PubMed: 9366401]

[37]. Hawiger D, Inaba K, Dorsett Y, Guo M, Mahnke K, Rivera M, Ravetch JV, Steinman RM, Nussenzweig MC. Dendritic cells induce peripheral T cell unresponsiveness under steady state conditions in vivo. J. Exp. Med. 2001; 194:769-779. [PubMed: 11560993]

[38]. Dhodapkar MV, Steinman RM. Antigen-bearing immature dendritic cells induce peptide-specific CD8(+) regulatory T cells in vivo in humans. Blood. 2002; 100:174-177. [PubMed: 12070024]

[39]. Dhodapkar MV, Steinman RM, Krasovsky J, Munz C, Bhardwaj N. Antigen-specific inhibition of effector T cell function in humans after injection of immature dendritic cells. J. Exp. Med. 2001; 193:233-238. [PubMed: 11208863]

[40]. Beyer T, Herrmann M, Reiser C, Bertling W, Hess J. Bacterial carriers and virus-like-particles as antigen delivery devices: role of dendritic cells in antigen presentation. Curr. Drug Targets Infect. Disord. 2001; 1:287-302. [PubMed: 12455402]

[41]. Rescigno M, Granucci F, Ricciardi-Castagnoli P. Molecular events of bacterial-induced maturation of dendritic cells. J. Clin. Immunol. 2000; 20:161-166. [PubMed: 10941823]

[42]. Jonuleit H, Kuhn U, Muller G, Steinbrink K, Paragnik L, Schmitt E, Knop J, Enk AH. Proinflammatory cytokines and prostaglandins induce maturation of potent immunostimulatory dendritic cells under fetal calf serum-free conditions. Eur. J. Immunol. 1997; 27:3135-3142. [PubMed: 9464798]

[43]. Mackey MF, Gunn JR, Maliszewsky C, Kikutani H, Noelle RJ, Barth RJ Jr. Dendritic cells require maturation via CD40 to generate protective antitumor immunity. J. Immunol. 1998; 161:2094-2098. [PubMed: 9725199]

[44]. Mackey MF, Barth RJ Jr. Noelle RJ. The role of CD40/CD154 interactions in the priming, differentiation, and effector function of helper and cytotoxic T cells. J. Leukoc. Biol. 1998; 63:418-428. [PubMed: 9544571]

[45]. Caux C, Massacrier C, Vanbervliet B, Dubois B, Van Kooten C, Durand I, Banchereau J. Activation of human dendritic cells through CD40 cross-linking. J. Exp. Med. 1994; 180:12631272. [PubMed: 7523569]

[46]. Aiba S, Tagami H. Dendritic cells play a crucial role in innate immunity to simple chemicals. J. Invest. Dermatol. Symp. Proc. 1999; 4:158-163.

[47]. Aiba S, Tagami H. Dendritic cell activation induced by various stimuli, e.g. exposure to microorganisms, their products, cytokines, and simple chemicals as well as adhesion to extracellular matrix. J. Dermatol. Sci. 1998; 20:1-13. [PubMed: 10342743]

[48]. Aiba S, Terunuma A, Manome H, Tagami H. Dendritic cells differently respond to haptens and irritants by their production of cytokines and expression of co-stimulatory molecules. Eur. J. Immunol. 1997; 27:3031-3038. [PubMed: 9394834]

[49]. Forster R, Davalos-Misslitz AC, Rot A. CCR7 and its ligands: balancing immunity and tolerance. Nat. Rev. Immunol. 2008; 8:362-371. [PubMed: 18379575] 
[50]. Verhasselt V, Vosters O, Beuneu C, Nicaise C, Stordeur P, Goldman M. Induction of FOXP3expressing regulatory CD4pos T cells by human mature autologous dendritic cells. Eur. J. Immunol. 2004; 34:762-772. [PubMed: 14991606]

[51]. Vieira PL, de Jong EC, Wierenga EA, Kapsenberg ML, Kalinski P. Development of Th1inducing capacity in myeloid dendritic cells requires environmental instruction. J. Immunol. 2000; 164:4507-4512. [PubMed: 10779751]

[52]. Walker LS, Abbas AK. The enemy within: keeping self-reactive T cells at bay in the periphery. Nat. Rev. Immunol. 2002; 2:11-19. [PubMed: 11908514]

[53]. Zitvogel L, Tesniere A, Kroemer G. Cancer despite immunosurveillance: immunoselection and immunosubversion. Nat. Rev. Immunol. 2006; 6:715-727. [PubMed: 16977338]

[54]. Emens LA. A new twist on autologous cancer vaccines. Cancer Biol. Ther. 2003; 2:161-163. [PubMed: 12750555]

[55]. Lizee G, Radvanyi LG, Overwijk WW, Hwu P. Improving antitumor immune responses by circumventing immunoregulatory cells and mechanisms. Clin. Cancer Res. 2006; 12:4794-4803. [PubMed: 16914564]

[56]. Iwasaki A, Medzhitov R. Toll-like receptor control of the adaptive immune responses. Nat. Immunol. 2004; 5:987-995. [PubMed: 15454922]

[57]. Pasare C, Medzhitov R. Toll-like receptors: linking innate and adaptive immunity. Adv. Exp. Med. Biol. 2005; 560:11-18. [PubMed: 15932016]

[58]. Rakoff-Nahoum S, Medzhitov R. Toll-like receptors and cancer. Nat. Rev. Cancer. 2009; 9:5763. [PubMed: 19052556]

[59]. West MA, Wallin RP, Matthews SP, Svensson HG, Zaru R, Ljunggren HG, Prescott AR, Watts C. Enhanced dendritic cell antigen capture via toll-like receptor-induced actin remodeling. Science. 2004; 305:1153-1157. [PubMed: 15326355]

[60]. Yates RM, Russell DG. Phagosome maturation proceeds independently of stimulation of toll-like receptors 2 and 4. Immunity. 2005; 23:409-417. [PubMed: 16226506]

[61]. Blander JM, Medzhitov R. Toll-dependent selection of microbial antigens for presentation by dendritic cells. Nature. 2006; 440:808-812. [PubMed: 16489357]

[62]. Blander JM, Medzhitov R. Regulation of phagosome maturation by signals from toll-like receptors. Science. 2004; 304:1014-1018. [PubMed: 15143282]

[63]. Pasare C, Medzhitov R. Toll-dependent control mechanisms of CD4 T cell activation. Immunity. 2004; 21:733-741. [PubMed: 15539158]

[64]. Yang Y, Huang CT, Huang X, Pardoll DM. Persistent Toll-like receptor signals are required for reversal of regulatory T cell-mediated CD8 tolerance. Nat. Immunol. 2004; 5:508-515. [PubMed: 15064759]

[65]. Lang KS, Recher M, Junt T, Navarini AA, Harris NL, Freigang S, Odermatt B, Conrad C, Ittner LM, Bauer S, Luther SA, Uematsu S, Akira S, Hengartner H, Zinkernagel RM. Toll-like receptor engagement converts T-cell autoreactivity into overt autoimmune disease. Nat. Med. 2005; 11:138-145. [PubMed: 15654326]

[66]. Van Meirvenne S, Dullaers M, Heirman C, Straetman L, Michiels A, Thielemans K. In vivo depletion of $\mathrm{CD} 4+\mathrm{CD} 25+$ regulatory $\mathrm{T}$ cells enhances the antigen-specific primary and memory CTL response elicited by mature mRNA-electroporated dendritic cells. Mol. Ther. 2005; 12:922932. [PubMed: 16257383]

[67]. Shimizu J, Yamazaki S, Sakaguchi S. Induction of tumor immunity by removing CD25+CD4+ T cells: a common basis between tumor immunity and autoimmunity. J. Immunol. 1999; 163:52115218. [PubMed: 10553041]

[68]. Napolitani G, Rinaldi A, Bertoni F, Sallusto F, Lanzavecchia A. Selected Toll-like receptor agonist combinations synergistically trigger a $\mathrm{T}$ helper type 1-polarizing program in dendritic cells. Nat. Immunol. 2005; 6:769-776. [PubMed: 15995707]

[69]. Gautier G, Humbert M, Deauvieau F, Scuiller M, Hiscott J, Bates EE, Trinchieri G, Caux C, Garrone P. A type I interferon autocrine-paracrine loop is involved in Toll-like receptor-induced interleukin-12p70 secretion by dendritic cells. J. Exp. Med. 2005; 201:1435-1446. [PubMed: 15851485] 
[70]. Warger T, Osterloh P, Rechtsteiner G, Fassbender M, Heib V, Schmid B, Schmitt E, Schild H, Radsak MP. Synergistic activation of dendritic cells by combined Toll-like receptor ligation induces superior CTL responses in vivo. Blood. 2006; 108:544-550. [PubMed: 16537810]

[71]. Boonstra A, Rajsbaum R, Holman M, Marques R, Asselin-Paturel C, Pereira JP, Bates EE, Akira S, Vieira P, Liu YJ, Trinchieri G, O'Garra A. Macrophages and myeloid dendritic cells, but not plasmacytoid dendritic cells, produce IL-10 in response to MyD88- and TRIF-dependent TLR signals, and TLR-independent signals. J. Immunol. 2006; 177:7551-7558. [PubMed: 17114424]

[72]. Kawai T, Akira S. Toll-like receptor and RIG-I-like receptor signaling. Ann. N.Y. Acad. Sci. 2008; 1143:1-20. [PubMed: 19076341]

[73]. Rescigno M, Martino M, Sutherland CL, Gold MR, Ricciardi-Castagnoli P. Dendritic cell survival and maturation are regulated by different signaling pathways. J. Exp. Med. 1998; 188:2175-2180. [PubMed: 9841930]

[74]. Sato K, Nagayama H, Tadokoro K, Juji T, Takahashi TA. Extracellular signal-regulated kinase, stress-activated protein kinase/c-Jun N-terminal kinase, and p38mapk are involved in IL-10mediated selective repression of TNF-alpha-induced activation and maturation of human peripheral blood monocyte-derived dendritic cells. J. Immunol. 1999; 162:3865-3872. [PubMed: 10201904]

[75]. Re F, Strominger JL. Toll-like receptor 2 (TLR2) and TLR4 differentially activate human dendritic cells. J. Biol. Chem. 2001; 276:37692-37699. [PubMed: 11477091]

[76]. Caparros E, Munoz P, Sierra-Filardi E, Serrano-Gomez D, Puig-Kroger A, Rodriguez-Fernandez JL, Mellado M, Sancho J, Zubiaur M, Corbi AL. DC-SIGN ligation on dendritic cells results in ERK and PI3K activation and modulates cytokine production. Blood. 2006; 107:3950-3958. [PubMed: 16434485]

[77]. Hirata N, Yanagawa Y, Ebihara T, Seya T, Uematsu S, Akira S, Hayashi F, Iwabuchi K, Onoe K. Selective synergy in anti-inflammatory cytokine production upon cooperated signaling via TLR4 and TLR2 in murine conventional dendritic cells. Mol. Immunol. 2008; 45:2734-2742. [PubMed: 18372043]

[78]. Trompezinski S, Migdal C, Tailhardat M, Le Varlet B, Courtellemont P, Haftek M, Serres M. Characterization of early events involved in human dendritic cell maturation induced by sensitizers: cross talk between MAPK signalling pathways. Toxicol. Appl. Pharmacol. 2008; 230:397-406. [PubMed: 18495191]

[79]. Luft T, Maraskovsky E, Schnurr M, Knebel K, Kirsch M, Gorner M, Skoda R, Ho AD, Nawroth $\mathrm{P}$, Bierhaus A. Tuning the volume of the immune response: strength and persistence of stimulation determine migration and cytokine secretion of dendritic cells. Blood. 2004; 104:1066-1074. [PubMed: 15113760]

[80]. Luft T, Rodionova E, Maraskovsky E, Kirsch M, Hess M, Buchholtz C, Goerner M, Schnurr M, Skoda R, Ho AD. Adaptive functional differentiation of dendritic cells: integrating the network of extra- and intracellular signals. Blood. 2006; 107:4763-4769. [PubMed: 16527899]

[81]. Larange A, Antonios D, Pallardy M, Kerdine-Romer S. TLR7 and TLR8 agonists trigger different signaling pathways for human dendritic cell maturation. J. Leukoc. Biol. 2009; 85:673683. [PubMed: 19164127]

[82]. Ardeshna KM, Pizzey AR, Devereux S, Khwaja A. The PI3 kinase, p38 SAP kinase, and NFkappaB signal transduction pathways are involved in the survival and maturation of lipopolysaccharide-stimulated human monocyte-derived dendritic cells. Blood. 2000; 96:1039_ 1046. [PubMed: 10910920]

[83]. Boulton TG, Nye SH, Robbins DJ, Ip NY, Radziejewska E, Morgenbesser SD, DePinho RA, Panayotatos N, Cobb MH, Yancopoulos GD. ERKs: a family of protein-serine/threonine kinases that are activated and tyrosine phosphorylated in response to insulin and NGF. Cell. 1991; 65:663-675. [PubMed: 2032290]

[84]. Boulton TG, Cobb MH. Identification of multiple extracellular signal-regulated kinases (ERKs) with antipeptide antibodies. Cell Regul. 1991; 2:357-371. [PubMed: 1654126]

[85]. Derijard B, Hibi M, Wu IH, Barrett T, Su B, Deng T, Karin M, Davis RJ. JNK1: a protein kinase stimulated by UV light and Ha-Ras that binds and phosphorylates the c-Jun activation domain. Cell. 1994; 76:1025-1037. [PubMed: 8137421] 
[86]. Kyriakis JM, Banerjee P, Nikolakaki E, Dai T, Rubie EA, Ahmad MF, Avruch J, Woodgett JR. The stress-activated protein kinase subfamily of c-Jun kinases. Nature. 1994; 369:156-160. [PubMed: 8177321]

[87]. Lee JC, Laydon JT, McDonnell PC, Gallagher TF, Kumar S, Green D, McNulty D, Blumenthal MJ, Heys JR, Landvatter SW, Strickler JE, McLaughlin MM, Siemens IR, Fisher SM, Livi GP, White JR, Adams JL, Young PR. A protein kinase involved in the regulation of inflammatory cytokine biosynthesis. Nature. 1994; 372:739-746. [PubMed: 7997261]

[88]. Han J, Lee JD, Bibbs L, Ulevitch RJ. A MAP kinase targeted by endotoxin and hyperosmolarity in mammalian cells. Science. 1994; 265:808-811. [PubMed: 7914033]

[89]. Zhang J, Yang PL, Gray NS. Targeting cancer with small molecule kinase inhibitors. Nat. Rev. Cancer. 2009; 9:28-39. [PubMed: 19104514]

[90]. Beutler BA. TLRs and innate immunity. Blood. 2009; 113:1399-1407. [PubMed: 18757776]

[91]. Hacker H, Redecke V, Blagoev B, Kratchmarova I, Hsu LC, Wang GG, Kamps MP, Raz E, Wagner H, Hacker G, Mann M, Karin M. Specificity in Toll-like receptor signalling through distinct effector functions of TRAF3 and TRAF6. Nature. 2006; 439:204-207. [PubMed: 16306937]

[92]. Sato S, Sanjo H, Takeda K, Ninomiya-Tsuji J, Yamamoto M, Kawai T, Matsumoto K, Takeuchi $\mathrm{O}$, Akira S. Essential function for the kinase TAK1 in innate and adaptive immune responses. Nat. Immunol. 2005; 6:1087-1095. [PubMed: 16186825]

[93]. Yamamoto M, Okamoto T, Takeda K, Sato S, Sanjo H, Uematsu S, Saitoh T, Yamamoto N, Sakurai H, Ishii KJ, Yamaoka S, Kawai T, Matsuura Y, Takeuchi O, Akira S. Key function for the Ubc13 E2 ubiquitin-conjugating enzyme in immune receptor signaling. Nat. Immunol. 2006; 7:962-970. [PubMed: 16862162]

[94]. Pearson G, Robinson F, Gibson T. Beers, Xu BE, Karandikar M, Berman K, Cobb MH. Mitogenactivated protein (MAP) kinase pathways: regulation and physiological functions. Endocr. Rev. 2001; 22:153-183. [PubMed: 11294822]

[95]. Nakayama K, Ota Y, Okugawa S, Ise N, Kitazawa T, Tsukada K, Kawada M, Yanagimoto S, Kimura S. Raf1 plays a pivotal role in lipopolysaccharide-induced activation of dendritic cells. Biochem. Biophys. Res. Commun. 2003; 308:353-360. [PubMed: 12901876]

[96]. Zimmermann S, Rommel C, Ziogas A, Lovric J, Moelling K, Radziwill G. MEK1 mediates a positive feedback on Raf-1 activity independently of Ras and Src. Oncogene. 1997; 15:15031511. [PubMed: 9380402]

[97]. Wang C, Deng L, Hong M, Akkaraju GR, Inoue J, Chen ZJ. TAK1 is a ubiquitin-dependent kinase of MKK and IKK. Nature. 2001; 412:346-351. [PubMed: 11460167]

[98]. Junttila MR, Li SP, Westermarck J. Phosphatase-mediated crosstalk between MAPK signaling pathways in the regulation of cell survival. FASEB J. 2008; 22:954-965. [PubMed: 18039929]

[99]. Agrawal A, Dillon S, Denning TL, Pulendran B. ERK1-/- mice exhibit Th1 cell polarization and increased susceptibility to experimental autoimmune encephalomyelitis. J. Immunol. 2006; 176:5788-5796. [PubMed: 16670284]

[100]. Escors D, Lopes L, Lin R, Hiscott J, Akira S, Davis RJ, Collins MK. Targeting dendritic cell signaling to regulate the response to immunization. Blood. 2008; 111:3050-3061. [PubMed: 18180378]

[101]. Puig-Kroger A, Relloso M, Fernandez-Capetillo O, Zubiaga A, Silva A, Bernabeu C, Corbi AL. Extracellular signal-regulated protein kinase signaling pathway negatively regulates the phenotypic and functional maturation of monocyte-derived human dendritic cells. Blood. 2001; 98:2175-2182. [PubMed: 11568005]

[102]. Yanagawa Y, Onoe K. Enhanced IL-10 production by TLR4- and TLR2-primed dendritic cells upon TLR restimulation. J. Immunol. 2007; 178:6173-6180. [PubMed: 17475844]

[103]. Slack EC, Robinson MJ, Hernanz-Falcon P, Brown GD, Williams DL, Schweighoffer E, Tybulewicz VL, Reis e Sousa C. Syk-dependent ERK activation regulates IL-2 and IL-10 production by DC stimulated with zymosan. Eur. J. Immunol. 2007; 37:1600-1612. [PubMed: 17458858] 
[104]. Qian C, Jiang X, An H, Yu Y, Guo Z, Liu S, Xu H, Cao X. TLR agonists promote ERKmediated preferential IL-10 production of regulatory dendritic cells (diffDCs), leading to NK-cell activation. Blood. 2006; 108:2307-2315. [PubMed: 16778140]

[105]. Manicassamy S, Ravindran R, Deng J, Oluoch H, Denning TL, Kasturi SP, Rosenthal KM, Evavold BD, Pulendran B. Toll-like receptor 2-dependent induction of vitamin A-metabolizing enzymes in dendritic cells promotes T regulatory responses and inhibits autoimmunity. Nat. Med. 2009; 15:401-409. [PubMed: 19252500]

[106]. Ehlers M, Ravetch JV. Opposing effects of Toll-like receptor stimulation induce autoimmunity or tolerance. Trends Immunol. 2007; 28:74-79. [PubMed: 17197239]

[107]. Conroy H, Marshall NA, Mills KH. TLR ligand suppression or enhancement of Treg cells? A double-edged sword in immunity to tumours. Oncogene. 2008; 27:168-180. [PubMed: 18176598]

[108]. Jackson AM, Mulcahy LA, Zhu XW, O’Donnell D, Patel PM. Tumour-mediated disruption of dendritic cell function: inhibiting the MEK1/2-p44/42 axis restores IL-12 production and Th1generation. Int. J. Cancer. 2008; 123:623-632. [PubMed: 18478568]

[109]. Fujita H, Asahina A, Komine M, Tamaki K. ERK inhibitor PD98059 promotes the phenotypic and functional maturation of murine resident Langerhans cells. J. Dermatol. 2007; 34:403-406. [PubMed: 17535410]

[110]. Yanagawa Y, Iijima N, Iwabuchi K, Onoe K. Activation of extracellular signal-related kinase by TNF-alpha controls the maturation and function of murine dendritic cells. J. Leukoc. Biol. 2002; 71:125-132. [PubMed: 11781388]

[111]. Roberts PJ, Der CJ. Targeting the Raf-MEK-ERK mitogen-activated protein kinase cascade for the treatment of cancer. Oncogene. 2007; 26:3291-3310. [PubMed: 17496923]

[112]. Ozao-Choy J, Ma G, Kao J, Wang GX, Meseck M, Sung M, Schwartz M, Divino CM, Pan PY, $\mathrm{Chen} \mathrm{SH}$. The novel role of tyrosine kinase inhibitor in the reversal of immune suppression and modulation of tumor microenvironment for immune-based cancer therapies. Cancer Res. 2009; 69:2514-2522. [PubMed: 19276342]

[113]. Xin H, Zhang C, Herrmann A, Du Y, Figlin R, Yu H. Sunitinib inhibition of Stat3 induces renal cell carcinoma tumor cell apoptosis and reduces immunosuppressive cells. Cancer Res. 2009; 69:2506-2513. [PubMed: 19244102]

[114]. Ninomiya-Tsuji J, Kishimoto K, Hiyama A, Inoue J, Cao Z, Matsumoto K. The kinase TAK1 can activate the NIK-I kappaB as well as the MAP kinase cascade in the IL-1 signalling pathway. Nature. 1999; 398:252-256. [PubMed: 10094049]

[115]. Moriguchi T, Kuroyanagi N, Yamaguchi K, Gotoh Y, Irie K, Kano T, Shirakabe K, Muro Y, Shibuya H, Matsumoto K, Nishida E, Hagiwara M. A novel kinase cascade mediated by mitogen-activated protein kinase kinase 6 and MKK3. J. Biol. Chem. 1996; 271:13675-13679. [PubMed: 8663074]

[116]. Zarubin T, Han J. Activation and signaling of the p38 MAP kinase pathway. Cell Res. 2005; 15:11-18. [PubMed: 15686620]

[117]. Arrighi JF, Rebsamen M, Rousset F, Kindler V, Hauser C. A critical role for p38 mitogenactivated protein kinase in the maturation of human blood-derived dendritic cells induced by lipopolysaccharide, TNF-alpha, and contact sensitizers. J. Immunol. 2001; 166:3837-3845. [PubMed: 11238627]

[118]. Yu Q, Kovacs C, Yue FY, Ostrowski MA. The role of the p38 mitogen-activated protein kinase, extracellular signal-regulated kinase, and phosphoinositide-3-OH kinase signal transduction pathways in CD40 ligand-induced dendritic cell activation and expansion of virus-specific CD8+ T cell memory responses. J. Immunol. 2004; 172:6047-6056. [PubMed: 15128788]

[119]. Lu HT, Yang DD, Wysk M, Gatti E, Mellman I, Davis RJ, Flavell RA. Defective IL-12 production in mitogen-activated protein (MAP) kinase kinase 3 (Mkk3)-deficient mice. EMBO J. 1999; 18:1845-1857. [PubMed: 10202148]

[120]. Morton S, Davis RJ, Cohen P. Signalling pathways involved in multisite phosphorylation of the transcription factor ATF-2. FEBS Lett. 2004; 572:177-183. [PubMed: 15304344]

[121]. Saccani S, Pantano S, Natoli G. p38-Dependent marking of inflammatory genes for increased NF-kappa B recruitment. Nat. Immunol. 2002; 3:69-75. [PubMed: 11743587] 
[122]. Xiao YQ, Malcolm K, Worthen GS, Gardai S, Schiemann WP, Fadok VA, Bratton DL, Henson PM. Cross-talk between ERK and p38 MAPK mediates selective suppression of proinflammatory cytokines by transforming growth factor-beta. J. Biol. Chem. 2002; 277:1488414893. [PubMed: 11842088]

[123]. Li SP, Junttila MR, Han J, Kahari VM, Westermarck J. p38 Mitogen-activated protein kinase pathway suppresses cell survival by inducing dephosphorylation of mitogen-activated protein/ extracellular signal-regulated kinase kinase1,2. Cancer Res. 2003; 63:3473-3477. [PubMed: 12839928]

[124]. Zhang B, Xia HQ, Cleghorn G, Gobe G, West M, Wei MQ. A highly efficient and consistent method for harvesting large volumes of high-titre lentiviral vectors. Gene Ther. 2001; 8:17451751. [PubMed: 11892843]

[125]. Gupta S, Barrett T, Whitmarsh AJ, Cavanagh J, Sluss HK, Derijard B, Davis RJ. Selective interaction of JNK protein kinase isoforms with transcription factors. EMBO J. 1996; 15:27602770. [PubMed: 8654373]

[126]. Morton S, Davis RJ, McLaren A, Cohen P. A reinvestigation of the multisite phosphorylation of the transcription factor c-Jun. EMBO J. 2003; 22:3876-3886. [PubMed: 12881422]

[127]. Hammaker DR, Boyle DL, Inoue T, Firestein GS. Regulation of the JNK pathway by TGF-beta activated kinase 1 in rheumatoid arthritis synoviocytes. Arthritis Res. Ther. 2007; 9:R57. [PubMed: 17559674]

[128]. Nakahara T, Uchi H, Urabe K, Chen Q, Furue M, Moroi Y. Role of c-Jun N-terminal kinase on lipopolysaccharide induced maturation of human monocyte-derived dendritic cells. Int. Immunol. 2004; 16:1701-1709. [PubMed: 15477228]

[129]. Sen R, Baltimore D. Inducibility of kappa immunoglobulin enhancer-binding protein Nf-kappa B by a posttranslational mechanism. Cell. 1986; 47:921-928. [PubMed: 3096580]

[130]. Ghosh S, Karin M. Missing pieces in the NF-kappaB puzzle. Cell. 2002; 109:S81-S96. [PubMed: 11983155]

[131]. Weih DS, Yilmaz ZB, Weih F. Essential role of RelB in germinal center and marginal zone formation and proper expression of homing chemokines. J. Immunol. 2001; 167:1909-1919. [PubMed: 11489970]

[132]. Weih F, Carrasco D, Durham SK, Barton DS, Rizzo CA, Ryseck RP, Lira SA, Bravo R. Multiorgan inflammation and hematopoietic abnormalities in mice with a targeted disruption of RelB, a member of the NF-kappa B/Rel family. Cell. 1995; 80:331-340. [PubMed: 7834753]

[133]. Caamano JH, Rizzo CA, Durham SK, Barton DS, Raventos-Suarez C, Snapper CM, Bravo R. Nuclear factor (NF)-kappa B2 (p100/p52) is required for normal splenic microarchitecture and B cell-mediated immune responses. J. Exp. Med. 1998; 187:185-196. [PubMed: 9432976]

[134]. Franzoso G, Carlson L, Poljak L, Shores EW, Epstein S, Leonardi A, Grinberg A, Tran T, Scharton-Kersten T, Anver M, Love P, Brown K, Siebenlist U. Mice deficient in nuclear factor (NF)-kappa B/p52 present with defects in humoral responses, germinal center reactions, and splenic microarchitecture. J. Exp. Med. 1998; 187:147-159. [PubMed: 9432973]

[135]. Carrasco D, Cheng J, Lewin A, Warr G, Yang H, Rizzo C, Rosas F, Snapper C, Bravo R. Multiple hemopoietic defects and lymphoid hyperplasia in mice lacking the transcriptional activation domain of the c-Rel protein. J. Exp. Med. 1998; 187:973-984. [PubMed: 9529314]

[136]. Poljak L, Carlson L, Cunningham K, Kosco-Vilbois MH, Siebenlist U. Distinct activities of p52/NF-kappa B required for proper secondary lymphoid organ microarchitecture: functions enhanced by Bcl-3. J. Immunol. 1999; 163:6581-6588. [PubMed: 10586052]

[137]. Burkly L, Hession C, Ogata L, Reilly C, Marconi LA, Olson D, Tizard R, Cate R, Lo D. Expression of relB is required for the development of thymic medulla and dendritic cells. Nature. 1995; 373:531-536. [PubMed: 7845467]

[138]. Martin E, O'Sullivan B, Low P, Thomas R. Antigen-specific suppression of a primed immune response by dendritic cells mediated by regulatory $\mathrm{T}$ cells secreting interleukin-10. Immunity. 2003; 18:155-167. [PubMed: 12530984]

[139]. Rothwarf DM, Karin M. The NF-kappa B activation pathway: a paradigm in information transfer from membrane to nucleus. Sci. STKE. 1999; 1999:RE1. [PubMed: 11865184] 
[140]. Edwards MR, Bartlett NW, Clarke D, Birrell M, Belvisi M, Johnston SL. Targeting the NFkappaB pathway in asthma and chronic obstructive pulmonary disease. Pharmacol. Ther. 2009; 121:1-13. [PubMed: 18950657]

[141]. Wang RF, Miyahara Y, Wang HY. Toll-like receptors and immune regulation: implications for cancer therapy. Oncogene. 2008; 27:181-189. [PubMed: 18176599]

[142]. Lee CH, Jeon YT, Kim SH, Song YS. NF-kappaB as a potential molecular target for cancer therapy. Biofactors. 2007; 29:19-35. [PubMed: 17611291]

[143]. Akira S, Uematsu S, Takeuchi O. Pathogen recognition and innate immunity. Cell. 2006; 124:783-801. [PubMed: 16497588]

[144]. Scheidereit C. Signal transduction. Docking IkappaB kinases. Nature. 1998; 395:225-226. [PubMed: 9751044]

[145]. Courtois G, Smahi A, Israel A. NEMO/IKK gamma: linking NF-kappa B to human disease. Trends Mol. Med. 2001; 7:427-430. [PubMed: 11597506]

[146]. Karin M. How NF-kappaB is activated? the role of the IkappaB kinase (IKK) complex. Oncogene. 1999; 18:6867-6874. [PubMed: 10602462]

[147]. Dawson S, Hastings R, Takayanagi K, Reynolds S, Low P, Billett M, Mayer RJ. The 26Sproteasome: regulation and substrate recognition. Mol. Biol. Rep. 1997; 24:39-44. [PubMed: 9228279]

[148]. Hu MC, Wang Y, Qiu WR, Mikhail A, Meyer CF, Tan TH. Hematopoietic progenitor kinase-1 (HPK1) stress response signaling pathway activates IkappaB kinases (IKK-alpha/beta) and IKKbeta is a developmentally regulated protein kinase. Oncogene. 1999; 18:5514-5524. [PubMed: 10523828]

[149]. Li Q, Van Antwerp D, Mercurio F, Lee KF, Verma IM. Severe liver degeneration in mice lacking the IkappaB kinase 2 gene. Science. 1999; 284:321-325. [PubMed: 10195897]

[150]. Takeda K, Takeuchi O, Tsujimura T, Itami S, Adachi O, Kawai T, Sanjo H, Yoshikawa K, Terada N, Akira S. Limb and skin abnormalities in mice lacking IKKalpha. Science. 1999; 284:313-316. [PubMed: 10195895]

[151]. Li ZW, Chu W, Hu Y, Delhase M, Deerinck T, Ellisman M, Johnson R, Karin M. The IKKbeta subunit of IkappaB kinase (IKK) is essential for nuclear factor kappaB activation and prevention of apoptosis. J. Exp. Med. 1999; 189:1839-1845. [PubMed: 10359587]

[152]. Hacker H, Karin M. Regulation and function of IKK and IKK-related kinases. Sci. STKE. 2006:re13. [PubMed: 17047224]

[153]. Dejardin E, Droin NM, Delhase M, Haas E, Cao Y, Makris C, Li ZW, Karin M, Ware CF, Green DR. The lymphotoxin-beta receptor induces different patterns of gene expression via two NF-kappaB pathways. Immunity. 2002; 17:525-535. [PubMed: 12387745]

[154]. Novack DV, Yin L, Hagen-Stapleton A, Schreiber RD, Goeddel DV, Ross FP, Teitelbaum SL. The IkappaB function of NF-kappaB2 p100 controls stimulated osteoclastogenesis. J. Exp. Med. 2003; 198:771-781. [PubMed: 12939342]

[155]. Senftleben U, Cao Y, Xiao G, Greten FR, Krahn G, Bonizzi G, Chen Y, Hu Y, Fong A, Sun SC, Karin M. Activation by IKKalpha of a second, evolutionary conserved, NF-kappa B signaling pathway. Science. 2001; 293:1495-1499. [PubMed: 11520989]

[156]. Lawrence T, Bebien M. IKKalpha in the regulation of inflammation and adaptive immunity. Biochem. Soc. Trans. 2007; 35:270-272. [PubMed: 17371257]

[157]. Naumann M, Scheidereit C. Activation of NF-kappa B in vivo is regulated by multiple phosphorylations. EMBO J. 1994; 13:4597-4607. [PubMed: 7925300]

[158]. Ito K, Charron CE, Adcock IM. Impact of protein acetylation in inflammatory lung diseases. Pharmacol. Ther. 2007; 116:249-265. [PubMed: 17720252]

[159]. Chen LF, Mu Y, Greene WC. Acetylation of RelA at discrete sites regulates distinct nuclear functions of NF-kappaB. EMBO J. 2002; 21:6539-6548. [PubMed: 12456660]

[160]. Chen LF, Williams SA, Mu Y, Nakano H, Duerr JM, Buckbinder L, Greene WC. NF-kappaB RelA phosphorylation regulates RelA acetylation. Mol. Cell Biol. 2005; 25:7966-7975. [PubMed: 16135789] 
[161]. Breckpot K, Aerts-Toegaert C, Heirman C, Peeters U, Beyaert R, Aerts JL, Thielemans K. Attenuated expression of A20 markedly increases the efficacy of double-stranded RNA-activated dendritic cells as an anti-cancer vaccine. J. Immunol. 2009; 182:860-870. [PubMed: 19124729]

[162]. Kawai T, Akira S. Signaling to NF-kappaB by Toll-like receptors. Trends Mol. Med. 2007; 13:460-469. [PubMed: 18029230]

[163]. Coornaert B, Carpentier I, Beyaert R. A20: central gatekeeper in inflammation and immunity. J. Biol. Chem. 2009; 284:8217-8221. [PubMed: 19008218]

[164]. Shi M, Deng W, Bi E, Mao K, Ji Y, Lin G, Wu X, Tao Z, Li Z, Cai X, Sun S, Xiang C, Sun B. TRIM30 alpha negatively regulates TLR-mediated NF-kappa B activation by targeting TAB2 and TAB3 for degradation. Nat. Immunol. 2008; 9:369-377. [PubMed: 18345001]

[165]. Bowie AG. TRIM-ing down Tolls. Nat. Immunol. 2008; 9:348-350. [PubMed: 18349813]

[166]. Barisic S, Strozyk E, Peters N, Walczak H, Kulms D. Identification of PP2A as a crucial regulator of the NF-kappaB feedback loop: its inhibition by UVB turns NF-kappaB into a proapoptotic factor. Cell Death Differ. 2008; 15:1681-1690. [PubMed: 18583989]

[167]. Dixit VM, Green S, Sarma V, Holzman LB, Wolf FW, O’Rourke K, Ward PA, Prochownik EV, Marks RM. Tumor necrosis factor-alpha induction of novel gene products in human endothelial cells including a macrophage-specific chemotaxin. J. Biol. Chem. 1990; 265:2973-2978. [PubMed: 2406243]

[168]. Song XT, Evel-Kabler K, Shen L, Rollins L, Huang XF, Chen SY. A20 is an antigen presentation attenuator, and its inhibition overcomes regulatory $\mathrm{T}$ cell-mediated suppression. Nat. Med. 2008; 14:258-265. [PubMed: 18311150]

[169]. Beyaert R, Heyninck K, Van Huffel S. A20 and A20-binding proteins as cellular inhibitors of nuclear factor-kappa B-dependent gene expression and apoptosis. Biochem. Pharmacol. 2000; 60:1143-1151. [PubMed: 11007952]

[170]. Wertz IE, O'Rourke KM, Zhou H, Eby M, Aravind L, Seshagiri S, Wu P, Wiesmann C, Baker R, Boone DL, Ma A, Koonin EV, Dixit VM. De-ubiquitination and ubiquitin ligase domains of A20 downregulate NF-kappaB signalling. Nature. 2004; 430:694-699. [PubMed: 15258597]

[171]. Evans PC, Ovaa H, Hamon M, Kilshaw PJ, Hamm S, Bauer S, Ploegh HL, Smith TS. Zincfinger protein A20, a regulator of inflammation and cell survival, has de-ubiquitinating activity. Biochem. J. 2004; 378:727-734. [PubMed: 14748687]

[172]. Boone DL, Turer EE, Lee EG, Ahmad RC, Wheeler MT, Tsui C, Hurley P, Chien M, Chai S, Hitotsumatsu O, McNally E, Pickart C, Ma A. The ubiquitin-modifying enzyme A20 is required for termination of Toll-like receptor responses. Nat. Immunol. 2004; 5:1052-1060. [PubMed: 15334086]

[173]. Heyninck K, Beyaert R. A20 inhibits NF-kappaB activation by dual ubiquitin-editing functions. Trends Biochem. Sci. 2005; 30:1-4. [PubMed: 15653317]

[174]. Zhang SQ, Kovalenko A, Cantarella G, Wallach D. Recruitment of the IKK signalosome to the p55 TNF receptor: RIP and A20 bind to NEMO (IKKgamma) upon receptor stimulation. Immunity. 2000; 12:301-311. [PubMed: 10755617]

[175]. Saitoh T, Yamamoto M, Miyagishi M, Taira K, Nakanishi M, Fujita T, Akira S, Yamamoto N, Yamaoka S. A20 is a negative regulator of IFN regulatory factor 3 signaling. J. Immunol. 2005; 174:1507-1512. [PubMed: 15661910]

[176]. Wang YY, Li L, Han KJ, Zhai Z, Shu HB. A20 is a potent inhibitor of TLR3- and Sendai virusinduced activation of NF-kappaB and ISRE and IFN-beta promoter. FEBS Lett. 2004; 576:8690. [PubMed: 15474016]

[177]. Heyninck K, Beyaert R. The cytokine-inducible zinc finger protein A20 inhibits IL-1-induced NF-kappaB activation at the level of TRAF6. FEBS Lett. 1999; 442:147-150. [PubMed: 9928991]

[178]. Hutti JE, Turk BE, Asara JM, Ma A, Cantley LC, Abbott DW. IkappaB kinase beta phosphorylates the K63 deubiquitinase A20 to cause feedback inhibition of the NF-kappaB pathway. Mol. Cell Biol. 2007; 27:7451-7461. [PubMed: 17709380]

[179]. Breckpot K, Dullaers M, Bonehill A, van Meirvenne S, Heirman C, de Greef C, van der Bruggen P, Thielemans K. Lentivirally transduced dendritic cells as a tool for cancer immunotherapy. J. Gene Med. 2003; 5:654-667. [PubMed: 12898635] 
[180]. Bonehill A, Heirman C, Tuyaerts S, Michiels A, Breckpot K, Brasseur F, Zhang Y, Van Der Bruggen P, Thielemans K. Messenger RNA-electroporated dendritic cells presenting MAGE-A3 simultaneously in HLA class I and class II molecules. J. Immunol. 2004; 172:6649-6657. [PubMed: 15153480]

[181]. Breckpot K, Emeagi PU, Thielemans K. Lentiviral vectors for anti-tumor immunotherapy. Curr. Gene Ther. 2008; 8:438-448. [PubMed: 19075627]

[182]. Breckpot K, Aerts JL, Thielemans K. Lentiviral vectors for cancer immunotherapy: transforming infectious particles into therapeutics. Gene Ther. 2007; 14:847-862. [PubMed: 17361214]

[183]. Ribas A. Genetically modified dendritic cells for cancer immunotherapy. Curr. Gene Ther. 2005; 5:619-628. [PubMed: 16457651]

[184]. Van Tendeloo VF, Ponsaerts P, Berneman ZN. mRNA-based gene transfer as a tool for gene and cell therapy. Curr. Opin. Mol. Ther. 2007; 9:423-431. [PubMed: 17932806]

[185]. da Silva Correia J, Soldau K, Christen U, Tobias PS, Ulevitch RJ. Lipopolysaccharide is in close proximity to each of the proteins in its membrane receptor complex. transfer from CD14 to TLR4 and MD-2. J. Biol. Chem. 2001; 276:21129-21135. [PubMed: 11274165]

[186]. Pasare C, Medzhitov R. Toll pathway-dependent blockade of CD4+CD25+ T cell-mediated suppression by dendritic cells. Science. 2003; 299:1033-1036. [PubMed: 12532024]

[187]. Abdel-Wahab Z, Cisco R, Dannull J, Ueno T, Abdel-Wahab O, Kalady MF, Onaitis MW, Tyler DS, Pruitt SK. Cotransfection of DC with TLR4 and MART-1 RNA induces MART-1-specific responses. J. Surg. Res. 2005; 124:264-273. [PubMed: 15820257]

[188]. Bonehill A, Tuyaerts S, Van Nuffel AM, Heirman C, Bos TJ, Fostier K, Neyns B, Thielemans $\mathrm{K}$. Enhancing the T-cell stimulatory capacity of human dendritic cells by co-electroporation with CD40L, CD70 and constitutively active TLR4 encoding mRNA. Mol. Ther. 2008; 16:11701180. [PubMed: 18431362]

[189]. Cisco RM, Abdel-Wahab Z, Dannull J, Nair S, Tyler DS, Gilboa E, Vieweg J, Daaka Y, Pruitt SK. Induction of human dendritic cell maturation using transfection with RNA encoding a dominant positive toll-like receptor 4. J. Immunol. 2004; 172:7162-7168. [PubMed: 15153540]

[190]. Xu Y, Darcy PK, Kershaw MH. Tumor-specific dendritic cells generated by genetic redirection of Toll-like receptor signaling against the tumor-associated antigen, erbB2. Cancer Gene Ther. 2007; 14:773-780. [PubMed: 17599092]

[191]. Hamdy S, Molavi O, Ma Z, Haddadi A, Alshamsan A, Gobti Z, Elhasi S, Samuel J, Lavasanifar A. Co-delivery of cancer-associated antigen and Toll-like receptor 4 ligand in PLGA nanoparticles induces potent CD8+ T cell-mediated anti-tumor immunity. Vaccine. 2008; 26:5046-5057. [PubMed: 18680779]

[192]. Tan PH, Beutelspacher SC, Xue SA, Wang YH, Mitchell P, McAlister JC, Larkin DF, McClure MO, Stauss HJ, Ritter MA, Lombardi G, George AJ. Modulation of human dendritic-cell function following transduction with viral vectors: implications for gene therapy. Blood. 2005; 105:3824-3832. [PubMed: 15671441]

[193]. Breckpot K, Emeagi P, Dullaers M, Michiels A, Heirman C, Thielemans K. Activation of immature monocyte-derived dendritic cells after transduction with high doses of lentiviral vectors. Hum. Gene Ther. 2007; 18:536-546. [PubMed: 17576158]

[194]. Brown BD, Sitia G, Annoni A, Hauben E, Sergi LS, Zingale A, Roncarolo MG, Guidotti LG, Naldini L. In vivo administration of lentiviral vectors triggers a type I interferon response that restricts hepatocyte gene transfer and promotes vector clearance. Blood. 2007; 109:2797-2805. [PubMed: 17170119]

[195]. Beignon AS, McKenna K, Skoberne M, Manches O, DaSilva I, Kavanagh DG, Larsson M, Gorelick RJ, Lifson JD, Bhardwaj N. Endocytosis of HIV-1 activates plasmacytoid dendritic cells via Toll-like receptor-viral RNA interactions. J. Clin. Invest. 2005; 115:3265-3275. [PubMed: 16224540]

[196]. Fonteneau JF, Larsson M, Beignon AS, McKenna K, Dasilva I, Amara A, Liu YJ, Lifson JD, Littman DR, Bhardwaj N. Human immunodeficiency virus type 1 activates plasmacytoid dendritic cells and concomitantly induces the bystander maturation of myeloid dendritic cells. J. Virol. 2004; 78:5223-5232. [PubMed: 15113904] 
[197]. Pichlmair A, Diebold SS, Gschmeissner S, Takeuchi Y, Ikeda Y, Collins MK, Reis e Sousa C. Tubulovesicular structures within vesicular stomatitis virus $\mathrm{G}$ protein-pseudotyped lentiviral vector preparations carry DNA and stimulate antiviral responses via Toll-like receptor 9. J. Virol. 2007; 81:539-547. [PubMed: 17079284]

[198]. He Y, Zhang J, Donahue C, Falo LD Jr. Skin-derived dendritic cells induce potent CD8(+) T cell immunity in recombinant lentivector-mediated genetic immunization. Immunity. 2006; 24:643-656. [PubMed: 16713981]

[199]. Esslinger C, Chapatte L, Finke D, Miconnet I, Guillaume P, Levy F, MacDonald HR. In vivo administration of a lentiviral vaccine targets DCs and induces efficient CD8(+) T cell responses. J. Clin. Invest. 2003; 111:1673-1681. [PubMed: 12782670]

[200]. Dullaers M, Van Meirvenne S, Heirman C, Straetman L, Bonehill A, Aerts JL, Thielemans K, Breckpot K. Induction of effective therapeutic antitumor immunity by direct in vivo administration of lentiviral vectors. Gene Ther. 2006; 13:630-640. [PubMed: 16355115]

[201]. Palmowski MJ, Lopes L, Ikeda Y, Salio M, Cerundolo V, Collins MK. Intravenous injection of a lentiviral vector encoding NY-ESO-1 induces an effective CTL response. J. Immunol. 2004; 172:1582-1587. [PubMed: 14734738]

[202]. Kim JH, Majumder N, Lin H, Watkins S, Falo LD Jr. You Z. Induction of therapeutic antitumor immunity by in vivo administration of a lentiviral vaccine. Hum. Gene Ther. 2005; 16:12551266. [PubMed: 16259559]

[203]. Chapatte L, Colombetti S, Cerottini JC, Levy F. Efficient induction of tumor antigen-specific CD8+ memory T cells by recombinant lentivectors. Cancer Res. 2006; 66:1155-1160. [PubMed: 16424053]

[204]. Rowe HM, Lopes L, Ikeda Y, Bailey R, Barde I, Zenke M, Chain BM, Collins MK. Immunization with a lentiviral vector stimulates both CD4 and CD8 T cell responses to an ovalbumin transgene. Mol. Ther. 2006; 13:310-319. [PubMed: 16275163]

[205]. Andreakos E, Williams RO, Wales J, Foxwell BM, Feldmann M. Activation of NF-kappaB by the intracellular expression of NF-kappaB-inducing kinase acts as a powerful vaccine adjuvant. Proc. Natl. Acad. Sci. USA. 2006; 103:14459-14464. [PubMed: 16971487]

[206]. Akazawa T, Ebihara T, Okuno M, Okuda Y, Shingai M, Tsujimura K, Takahashi T, Ikawa M, Okabe M, Inoue N, Okamoto-Tanaka M, Ishizaki H, Miyoshi J, Matsumoto M, Seya T. Antitumor NK activation induced by the Toll-like receptor 3-TICAM-1 (TRIF) pathway in myeloid dendritic cells. Proc. Natl. Acad. Sci. USA. 2007; 104:252-257. [PubMed: 17190817]

[207]. Akazawa T, Shingai M, Sasai M, Ebihara T, Inoue N, Matsumoto M, Seya T. Tumor immunotherapy using bone marrow-derived dendritic cells overexpressing Toll-like receptor adaptors. FEBS Lett. 2007; 581:3334-3340. [PubMed: 17601575]

[208]. Rowe HM, Lopes L, Brown N, Efklidou S, Smallie T, Karrar S, Kaye PM, Collins MK. Expression of vFLIP in a lentiviral vaccine vector activates NF- $\{$ kappa $\} \mathrm{B}$, matures dendritic cells, and increases CD8+ T-cell responses. J. Virol. 2009; 83:1555-1562. [PubMed: 19036811]

[209]. Karwacz K, Mukherjee S, Apolonia L, Blundell MP, Bouma G, Escors D, Collins MK, Thrasher AJ. Nonintegrating lentivector vaccines stimulate prolonged T-cell and antibody responses and are effective in tumor therapy. J. Virol. 2009; 83:3094-3103. [PubMed: 19176629]

[210]. Raingeaud J, Whitmarsh AJ, Barrett T, Derijard B, Davis RJ. MKK3- and MKK6-regulated gene expression is mediated by the $\mathrm{p} 38$ mitogen-activated protein kinase signal transduction pathway. Mol. Cell Biol. 1996; 16:1247-1255. [PubMed: 8622669]

[211]. Kuate S, Wagner R, Uberla K. Development and characterization of a minimal inducible packaging cell line for simian immunodeficiency virus-based lentiviral vectors. J. Gene Med. 2002; 4:347-355. [PubMed: 12124977]

[212]. Werner SL, Kearns JD, Zadorozhnaya V, Lynch C, O’Dea E, Boldin MP, Ma A, Baltimore D, Hoffmann A. Encoding NF-kappaB temporal control in response to TNF: distinct roles for the negative regulators IkappaBalpha and A20. Genes Dev. 2008; 22:2093-2101. [PubMed: 18676814] 

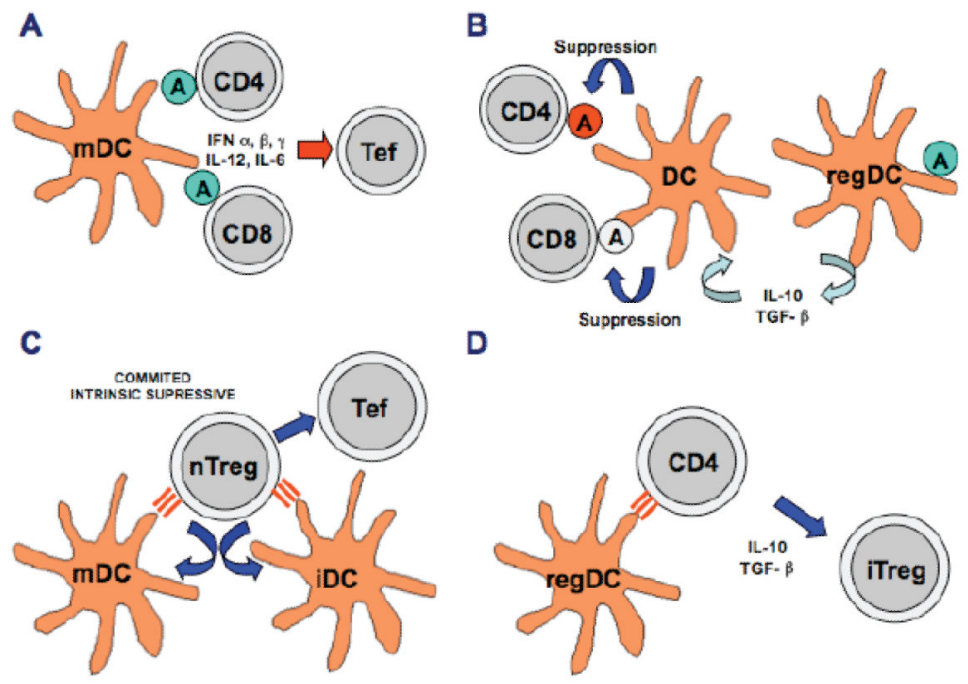

D



Fig. (1).

Anti-tumour immunity and tumour-induced suppression. In this figure, the four main mechanisms involving DC-T cell interaction in the regulation of tumour immunity are shown. (A) In an effective anti-tumour immunotherapy, mature DC (mDC) present TAA on their surface, represented as circled As. These antigens are recognised by specific CD4 and CD8 T cells in a pro-inflammatory setting (in the presence of the depicted cytokines), leading to differentiation of Th cells and CTL (T effector cells, Tef) from CD4 and CD8 T cells, respectively. (B) Antigen presentation also takes place in the tumour environment. In this setting, antigen-presenting cells such as DCreg induce antigen-specific and polyclonal tolerance leading to tumour-induced immune suppression. In the figure, a tumour-associated DCreg secretes tolerogenic cytokines IL-10 and TGF- $\beta$ and converts other non-commited DC into tolerogenic DC. In an analogous manner as in A, antigens are presented to CD4 and CD8 T cells, which do not further differentiate into effector T cells. (C) Most TAA are either auto-antigens or mutated auto-antigens (quasi-auto-antigens). Therefore, natural $\mathrm{T}$ regulatory cells (nTreg) recognise these TAA both in the context of mature DC and immature DC (iDC) by high-affinity binding of their TCR (depicted in the picture as parallel bars between DC and nTreg). These natural Treg actively suppress DC and T effector cells by several mechanisms not yet well characterised. (D) Tumour-associated DCreg present TAA to naive and memory CD4 T cells in the context of a suppressive environment, in the presence of cytokines such as IL-10 and TGF- $\beta$, as in (B). In this situation, CD4 T cells differentiate into induced Treg (iTreg). There is increasing evidence that induced Treg can suppress immune responses in similar ways to natural Treg, as in $(\mathbf{C})$. 


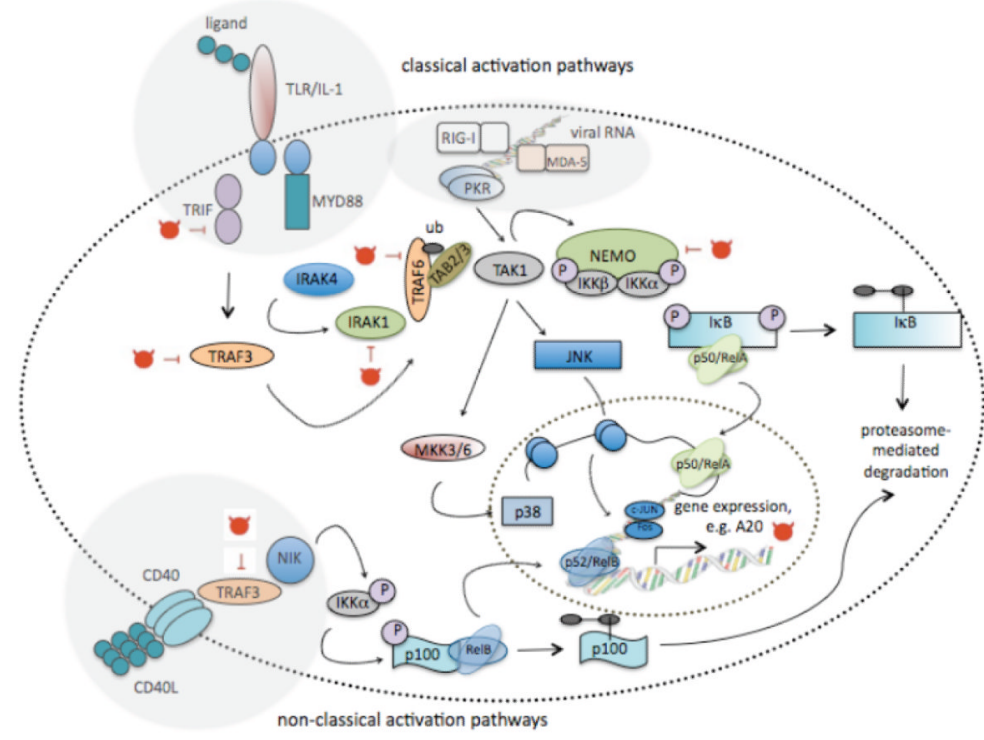

Fig. (2).

Schematic representation of the MAPK and NF- $\kappa$ B pathway that are reported to enhance DC maturation. The MAPK pathway is activated upon TLR stimulation, whereas activation of the transcription factor NF- $\mathrm{BB}$ can be initiated by a variety of stimuli, resulting in the socalled canonical or classical pathway, initiated upon ligation of TLR, RNA helicase and PKR versus the non-classical pathway, initiated by stimuli, such as CD40L, lymphotoxin- $\beta$ or RANKL. The MAPK p38 aids the binding of NF- $\kappa$ B to its consensus sequence by altering the chromatin structure of the DNA. Both the MAPK JNK and NF- $\kappa$ B pathway are important in DC maturation. They drive the expression of co-stimulatory, adhesion and antigen-presenting molecules, as well as pro-inflammatory cytokines. Moreover, NF- $\kappa \mathrm{B}$ drives the expression of several feedback proteins that attenuate activation, hence avoiding chronic inflammation. One of these, the zinc finger protein A20, which has ubiquitinating and de-ubiquitinating enzymatic activity, interacts with several adaptor proteins and has been studied as a mode to mimic persistent DC activation, as such enhancing the DC's potency to stimulate tumour antigen-specific $\mathrm{T}$ cells. 


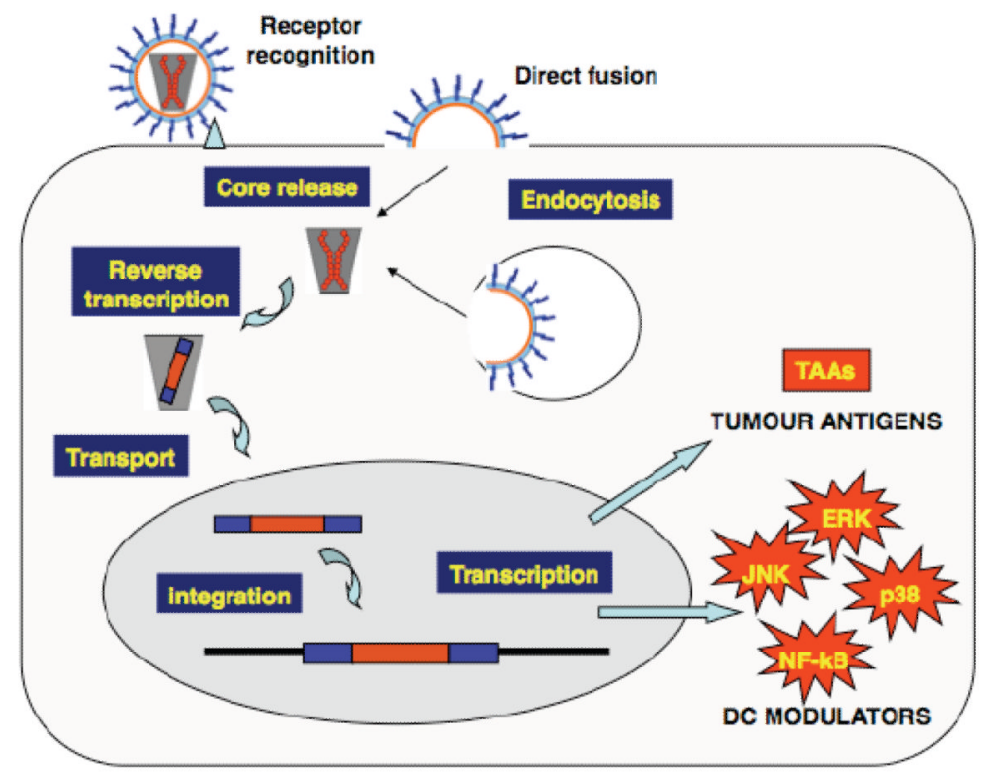

Fig. (3).

Targeting intracellular signalling pathways by genetic modification of DC. Gene therapy techniques allow the modification of DC function by introducing specific genes that modify intracellular signalling pathways. These signalling pathways will ultimately modify DC function by either increasing or suppressing their immunogenicity. In the figure, a viral vector carrying the therapeutic genes binds to the cell membrane (receptor recognition) and it fuses directly to the cell membrane leading to the core release. As it is the case of other vectors either based on retroviruses or not, virus-like particles can also be internalised by endocytosis. In the case of lentivectors (and other retrovirus-based vectors), through a process of reverse transcription, the therapeutic genetic information encoded as RNA is copied into a DNA version that is transported to the cell nucleus. Then, the therapeutic DNA genes are incorporated into the host genome, and they will lead to transcription and translation of both TAA and modulators of DC signalling (DC modulators). In this case, activation of ERK, JNK, p38 and NF- $\mathrm{KB}$ is depicted. Activation of these pathways will regulate DC maturation phenotype and cytokine secretion, and ultimately will enhance presentation of TAA to specific CD4 and CD8 T cells as shown in Fig. (1). 